\title{
Estimation of aerosol water and chemical composition from AERONET Sun-sky radiometer measurements at Cabauw, the Netherlands
}

\author{
A. J. van Beelen ${ }^{1}$, G. J. H. Roelofs ${ }^{1}$, O. P. Hasekamp ${ }^{2}$, J. S. Henzing ${ }^{3}$, and T. Röckmann ${ }^{1}$ \\ ${ }^{1}$ Institute for Marine and Atmospheric research Utrecht (IMAU), P.O. Box 80005, Utrecht University, Utrecht, \\ the Netherlands \\ ${ }^{2}$ Netherlands Institute for Space Research (SRON), Sorbonnelaan 2, 3584 CA Utrecht, the Netherlands \\ ${ }^{3}$ Netherlands Organisation for Applied Scientific Research, TNO, P.O. Box 80015, Utrecht, the Netherlands
}

Correspondence to: A. J. van Beelen (a.j.vanbeelen@uu.nl)

Received: 26 March 2013 - Published in Atmos. Chem. Phys. Discuss.: 10 June 2013

Revised: 11 April 2014 - Accepted: 24 April 2014 - Published: 18 June 2014

\begin{abstract}
Remote sensing of aerosols provides important information on atmospheric aerosol abundance. However, due to the hygroscopic nature of aerosol particles observed aerosol optical properties are influenced by atmospheric humidity, and the measurements do not unambiguously characterize the aerosol dry mass and composition, which complicates the comparison with aerosol models. In this study we derive aerosol water and chemical composition by a modeling approach that combines individual measurements of remotely sensed aerosol properties (e.g., optical thickness, single-scattering albedo, refractive index and size distribution) from an AERONET (Aerosol Robotic Network) Sunsky radiometer with radiosonde measurements of relative humidity. The model simulates water uptake by aerosols based on the chemical composition (e.g., sulfates, ammonium, nitrate, organic matter and black carbon) and size distribution. A minimization method is used to calculate aerosol composition and concentration, which are then compared to in situ measurements from the Intensive Measurement Campaign At the Cabauw Tower (IMPACT, May 2008, the Netherlands). Computed concentrations show good agreement with campaign-average (i.e., 1-14 May) surface observations (mean bias is $3 \%$ for $\mathrm{PM}_{10}$ and $4-25 \%$ for the individual compounds). They follow the day-to-day (synoptic) variability in the observations and are in reasonable agreement for daily average concentrations (i.e., mean bias is $5 \%$ for $\mathrm{PM}_{10}$ and black carbon, $10 \%$ for the inorganic salts and $18 \%$ for organic matter; root-mean-squared deviations are $26 \%$ for $\mathrm{PM}_{10}$ and $35-45 \%$ for the individual compounds).
\end{abstract}

The modeled water volume fraction is highly variable and strongly dependent on composition. During this campaign we find that it is $>0.5$ at approximately $80 \%$ relative humidity $(\mathrm{RH})$ when the aerosol composition is dominated by hygroscopic inorganic salts, and $<0.1$ when $\mathrm{RH}$ is below 40 $\%$, especially when the composition is dominated by less hygroscopic compounds such as organic matter. The scattering enhancement factor ( $\mathrm{f}(\mathrm{RH})$, the ratio of the scattering coefficient at $85 \% \mathrm{RH}$ and its dry value at $676 \mathrm{~nm}$ ) during 1-14 May is $2.6 \pm 0.5$. The uncertainty in AERONET (real) refractive index $(0.025-0.05)$ is the largest source of uncertainty in the modeled aerosol composition and leads to an uncertainty of $0.1-0.25(50-100 \%)$ in aerosol water volume fraction. Our methodology performs relatively well at Cabauw, but a better performance may be expected for regions with higher aerosol loading where the uncertainties in the AERONET inversions are smaller.

\section{Introduction}

Atmospheric aerosol particles interact directly and indirectly, i.e., through cloud albedo and lifetime, with radiation (Lohmann and Feichter, 2005). Aerosols influence weather and climate through visibility, sunshine duration, global radiation and temperature, as has been observed on regional (e.g., Van Beelen and Van Delden, 2012) and global scales (Wang et al., 2009; Wild et al., 2007; Forster et al., 2007). Relatively large uncertainties are associated with the aerosol radiative 
forcing. Estimates of radiative forcing from models range from -0.2 to $-0.9 \mathrm{~W} \mathrm{~m}^{-2}$ for the direct effect and -0.5 and $-1.5 \mathrm{~W} \mathrm{~m}^{-2}$ for the indirect effect (Forster et al., 2007; Quaas et al., 2009), while remote sensing estimates yield between -0.9 and $-1.9 \mathrm{~W} \mathrm{~m}^{-2}$ for the direct effect (Bellouin et al., 2005; Quaas et al., 2008) and $-0.2 \pm 0.1 \mathrm{~W} \mathrm{~m}^{-2}$ for the indirect effect (Quaas et al., 2008). More recent estimates of the aerosol radiative effects from models and remote sensing tend to converge (e.g., Bellouin et al., 2008; Myhre, 2009; Lohmann et al., 2010), but the uncertainty remains large (Loeb and Su, 2010; Schulz et al., 2010; Kahn, 2012; Bellouin et al., 2013; Myhre et al., 2013a). The uncertainty in aerosol forcing leads to large uncertainties in the estimates of climate sensitivity and future projections of climate change (Andreae et al., 2005; Myhre et al., 2013b).

A better characterization of the aerosol chemical composition and hygroscopicity is a necessary step in reducing these uncertainties. Aerosol properties such as size distribution and chemical composition are often measured in situ, for example during dedicated measurement campaigns (e.g., Yu et al., 2009; Kulmala et al., 2011). These measurements are relatively detailed and accurate, but they are only representative of small areas, most of which are in the Northern Hemisphere. Remotely sensed aerosol properties (e.g., from AERONET (Holben et al., 1998), MODIS (King et al., 1992) and POLDER/PARASOL (Deschamps et al., 1994; Tanré et al., 2011)) are available at larger spatial scales, but they reflect a contribution of aerosol water. The amount of aerosol water, and thus total aerosol mass and size, is strongly dependent on not only the aerosol composition (hygroscopicity) but also on relative humidity (RH). Discrepancies between remotely sensed aerosol properties and aerosol-climate models can thus be caused by the description of RH or aerosol processes in the model (e.g., Bian et al., 2009; Zhang et al., 2012), which complicates the validation of aerosol properties in aerosol-climate models.

In order to quantify the water contribution to AOT (aerosol optical thickness), several studies have retrieved aerosol wet growth or scattering enhancement factors due to aerosol water uptake. Schuster et al. (2009) derive the aerosol water fraction directly from measurements of the refractive index and mass conservation, but they apply an empirical relation to constrain the insoluble-to-soluble aerosol mass ratio. Jeong et al. (2007) derive vertical profiles of the aerosol humidification factor (the ratio of the scattering coefficient of aerosol at ambient RH and at dry (40\% RH) conditions) over the Southern Great Plains (USA) using airborne aerosol measurements of scattering and absorption under high- and low-humidity conditions, together with ambient RH, temperature and pressure profiles. Ganguly et al. (2009) use monthly average AERONET AOT, SSA (single-scattering albedo) and volume distribution, and MPLNET (Micro-pulse Lidar Network) extinction profiles to retrieve vertical profiles of aerosol chemical compounds, assuming specific size distributions for each aerosol component. Finally, Wang et al. (2013) use AERONET imaginary refractive index and SSA to retrieve columnar black carbon, brown carbon and dust in Beijing, China.

We present first results of a modeling approach that estimates the aerosol dry mass, the masses of several aerosol species, and aerosol water based on AERONET data from Cabauw (the Netherlands). The methodology is applied to individual measurements so that the short-term variability of the concentrations is resolved. The model simulates hygroscopic growth and optical characteristics of an aerosol population that is initialized with an a priori size distribution and chemical composition. In an iterative procedure the modeled aerosol properties are optimized in order to minimize the differences between observations and the model results. The resulting aerosol properties are compared with detailed measurements, with a focus on chemical composition, from the measurement campaign IMPACT (Intensive Measurement Period At the Cabauw Tower; Kulmala et al., 2009; 2011; Mensah et al., 2012) during May 2008. Aerosol characteristics resulting from this method can be used for a more consistent comparison of modeled and remotely sensed aerosol properties, as well as for a better understanding of aerosol-humidity and aerosol-cloud interactions (Feingold, 2003; Jeong et al., 2007; Koren et al., 2007; Roelofs and Kamphuis, 2009). Section 2 describes the model, the measurements and the minimization procedure, and presents a brief literature overview of specific weights and refractive indices associated with aerosol chemical components. In Sect. 3 we present the resulting aerosol chemical composition and compare it with measurements from IMPACT. Section 4 presents conclusions and a discussion of the results.

\section{Methodology}

\subsection{Model}

We use a microphysical aerosol model that calculates aerosol water uptake by considering aerosol chemical composition, size distribution and relative humidity. The aerosol optical properties are computed and compared to AERONET retrievals. Aerosol chemical composition and size distribution are found using an optimization method. This involves inverting the following equation:

$\boldsymbol{y}=F(\boldsymbol{x})+\boldsymbol{E}_{\boldsymbol{y}}$.

Here, $F$ is our forward model in which aerosol water uptake and optical properties are calculated. The state vector $\boldsymbol{x}$ contains the parameters that can be adjusted by the minimization routine. It is initialized with estimates of the mass concentrations of the dry aerosol chemical composition, size distribution and RH, which are then used to calculate aerosol water uptake and optical properties. The measurement vector $\boldsymbol{y}$ contains the AERONET retrievals and RH based on radiosonde measurements. $\boldsymbol{E}_{\boldsymbol{y}}$ denotes the 
Table 1. Overview of the parameters in the state vector $(\boldsymbol{x})$. Subscripts $\mathrm{f}$ and c denote fine and coarse mode, respectively.

\begin{tabular}{|c|c|c|}
\hline$x$ & Description & Remarks \\
\hline$m_{\mathrm{f}}, m_{\mathrm{c}}\left(\mathrm{SO}_{4}\right)$ & column-average mass mixing ratio sulfate & $\begin{array}{l}\text { The inorganic composition is determined from sulfate by using (fixed) } \\
\text { ammonium-to-sulfate and nitrate-to-sulfate ratios (see text). }\end{array}$ \\
\hline$m_{\mathrm{f}}, m_{\mathrm{c}}(\mathrm{OC})$ & mass mixing ratio organic carbon & $\begin{array}{l}\text { Water uptake is determined assuming } 20 \% \text { wt levoglucosan, } 40 \% \text { wt } \\
\text { succinic acid and } 40 \% \text { wt Suwannee River reference fulvic acid (Sven- } \\
\text { ningsson et al., 2006). }\end{array}$ \\
\hline$m_{\mathrm{f}}, m_{\mathrm{c}}(\mathrm{BC})$ & mass mixing ratio black carbon & - \\
\hline$N_{\mathrm{f}}, N_{\mathrm{c}}$ & column-average number concentration & - \\
\hline$\sigma_{\mathrm{f}}, \sigma_{\mathrm{c}}$ & (geometric) standard deviation & $\begin{array}{l}\text { Fine- and coarse-mode aerosols are assumed to be lognormally dis- } \\
\text { tributed. Geometric standard deviation of each mode can be varied by } \\
\text { the model. }\end{array}$ \\
\hline SPH & aerosol spherical fraction & $\begin{array}{l}\text { Only used when the }(440-870 \mathrm{~nm}) \text { Angström exponent is }<1.2 \text { and the } \\
\text { AOT is }>0.1 \text {, otherwise } \mathrm{SPH}=1 \text {. }\end{array}$ \\
\hline RH & column-average relative humidity & Initial guess is derived from sounding data. \\
\hline
\end{tabular}

Table 2. Overview of the parameters in the measurement vector $(\boldsymbol{y})$ and the uncertainties $\boldsymbol{E}_{y}$ in $\boldsymbol{y}$ used in this study.

\begin{tabular}{lll}
\hline $\boldsymbol{y}$ & Description & $\boldsymbol{E}_{\mathbf{y}}$ \\
\hline $\operatorname{RRI}(\lambda)$ & real part of the refractive index for four & $E_{\mathrm{RRI}}=\max \left[0.005 R R I / \mathrm{AOT}_{440 \mathrm{~nm}}, 0.025\right]$ \\
& wavelengths $(\lambda=440,676,870,1020 \mathrm{~nm})$ & \\
$\mathrm{IRI}(\lambda)$ & imaginary part of the refractive index & $E_{\mathrm{IRI}}=\mathrm{IRImax}\left[1 /\left(1+2.5\left(\mathrm{AOT}_{440 \mathrm{~nm}}-0.05\right)\right), 0.5\right]$ \\
$\mathrm{AOT}(\lambda)$ & aerosol optical thickness & $E_{\mathrm{AOT}}=0.01$ \\
$\mathrm{SSA}(\lambda)$ & single-scattering albedo & $E_{\mathrm{SSA}}=0.07 /\left(1+3\left(\mathrm{AOT}_{440 \mathrm{~nm}}-0.05\right)\right)$ \\
$V_{i}$ & volume distribution in 22 bins & $E_{V}=0.15 \mathrm{~V}^{*}$ \\
$\mathrm{SPH}$ & aerosol spherical fraction & $\sim 25 \%$ \\
$\mathrm{RH}$ & column-average relative humidity from soundings & $\sim 10 \%$ \\
\hline
\end{tabular}

* Approximation; see text.

uncertainty estimates of the parameters in $\boldsymbol{y}$. In an iterative procedure the parameters in $\boldsymbol{x}$ are adjusted so that the discrepancies between modeled and observed aerosol optical properties, size distribution and RH are minimized. An overview of the model structure is presented in Fig. 1.

\subsubsection{Aerosol: initialization, water uptake and optical properties}

Tables 1 and 2 present an overview of the parameters in $\boldsymbol{x}$ and $\boldsymbol{y}$ together with their uncertainty estimates used in this study. The model describes aerosol using dry mass mixing ratios, the number concentrations and (geometric) standard deviations of lognormal fine and coarse modes, assuming internally mixed randomly oriented spheroid particles. Aerosol chemical species considered by the model are sulfate (represented as a mixture of $\mathrm{H}_{2} \mathrm{SO}_{4}, \mathrm{NH}_{4} \mathrm{HSO}_{4}$ and $\left.\left(\mathrm{NH}_{4}\right)_{2} \mathrm{SO}_{4}\right)$, ammonium nitrate $\left(\mathrm{NH}_{4} \mathrm{NO}_{3}\right)$, sea salt $(\mathrm{NaCl})$, organic matter $(\mathrm{OC})$, black carbon (BC), and mineral dust. We remark that sea salt and mineral dust have been omitted from this study for reasons explained in Sect. 2.2.1.

The hygroscopic growth of aerosols can be described from their chemical composition by the Köhler relation (Köhler, 1936), a combination of Raoult's law for water activity $\left(a_{\mathrm{w}}\right)$ over a flat surface and the Kelvin equation for the curvature effect. We have neglected the Kelvin effect because it is very small compared to the Raoult effect for optically active aerosols with diameter larger than $0.1 \mu \mathrm{m}$ (Tang, 1996). The water activity $\left(a_{\mathrm{w}}\right)$ of an aerosol component is then directly linked to the ambient RH by $\% \mathrm{RH}=100 a_{\mathrm{w}}$. Measurements describing water uptake by $\mathrm{OC}$ are taken from Svenningsson et al. (2006). We have followed their assumption that water uptake by OC can be described by a mixture of levoglucosan, succinic acid and Suwannee River fulvic acid. Water uptake by ammonium sulfate, ammonium bisulfate, sulfuric acid, ammonium nitrate and sea salt is obtained from water activity measurements by Tang and Munkelwitz (1994), Tang (1996) and Tang et al. (1997). The density of the mixture of inorganic salts and water is estimated from measurements of the densities of the binary solutions of water and solute using a volume additivity rule (Tang, 1997). The total water uptake of a mixture of components is assumed to be the sum of the water uptake of each individual component (ZSR relation; Zdanovskii, 1936; Stokes and Robinson, 1966). Some inorganic salts display strong hysteresis behavior between a dry (crystalline) and wet state (Tang and Munkelwitz, 1993; Wang et al., 2008). Aerosols remain in the wet (deliquescent) 


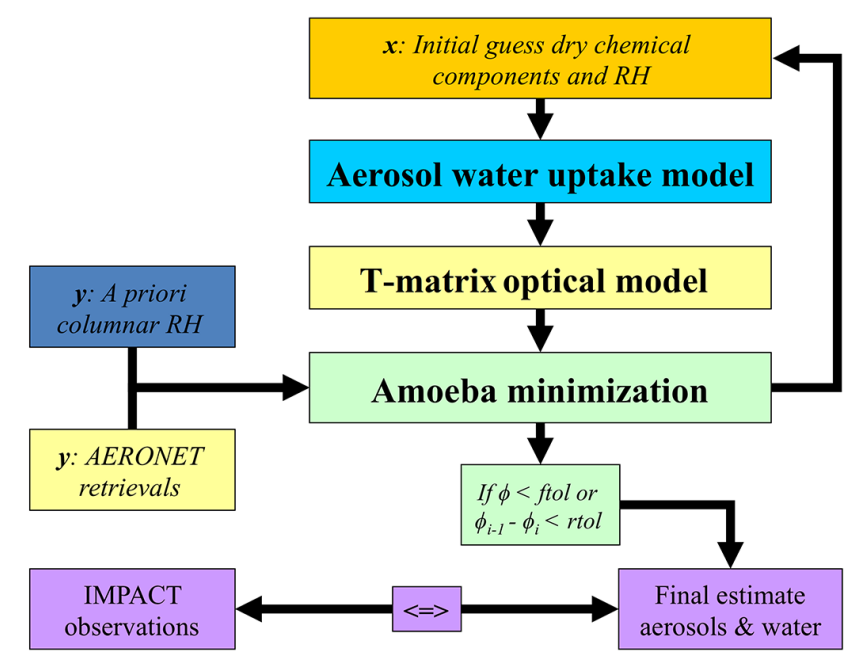

Figure 1. Flow diagram of the model. The state vector $\boldsymbol{x}$ contains the initial guess, which can be updated by the minimization routine which compares the output of the model with the measurement vector $\boldsymbol{y}$. When the cost function $\phi$ has reached a value lower than a certain threshold ftol, or when the improvement of $\phi$ in subsequent runs is smaller than $r t o l$, a final estimate of the aerosol is obtained and compared to observations.

state until RH drops below the efflorescence (crystallization) $\mathrm{RH}$. Boundary layer RH in the Netherlands is generally high enough for deliquescence. Also, for complex aerosol mixtures, the deliquescence RH is unknown but generally lower than its pure substances (Seinfeld and Pandis, 1998). Finally, organic constituents in mixed aerosols suppress the deliquescence behavior of inorganic salts (Marcolli and Krieger, 2006; Sjogren et al., 2007; Meyer et al., 2009).

Aerosol optical properties (i.e., AOT, SSA) are calculated using the $t$-matrix code described in Dubovik et al. (2006), taking into account the complex refractive index (RI) for each aerosol mode at four wavelengths $(440,676,870$ and $1020 \mathrm{~nm}$ ) and non-sphericity of the aerosol (Mishchenko et al., 1997). The RI of the mixture of inorganic salts and water is calculated with the partial molar refraction method (Moelwyn-Hughes, 1961; Stelson, 1990; Tang and Munkelwitz, 1994). The imaginary refractive index (IRI) of inorganic salts is assumed to be negligible. Weakly soluble or insoluble species (e.g., OC, BC, dust) generally do not homogeneously mix with the water-salt solution (e.g., Péré et al., 2009; Song et al., 2012). Since their mixing state and molecular mass is poorly known, we assume that the final RI for each mode is represented by the volume-weighted average RI of the wet inorganic salts and the other components (Lesins et al., 2002). This method can lead to an overestimation of the absorption by aged black carbon of up to $35 \%$ (Oshima et al., 2009) and thus an underestimation of the amount of $\mathrm{BC}$, but this has a smaller impact than the uncertainty in its refractive index and density (e.g., Schuster et al., 2005). Erlick (2006) and Erlick et al. (2011) show that the choice of
Table 3. Specific densities for the aerosol chemical components.

\begin{tabular}{llll}
\hline Compound & Dry density & Range & Reference \\
\hline$\left(\mathrm{NH}_{4}\right)_{2} \mathrm{SO}_{4}$ & 1.76 & - & 1 \\
$\mathrm{NH}_{4} \mathrm{HSO}_{4}$ & 1.78 & - & 1 \\
$\mathrm{H}_{2} \mathrm{SO}_{4}$ & 1.841 & - & 2 \\
$\mathrm{NaCl}$ & 2.165 & - & 3,4 \\
Organic matter & $1.547^{*}$ & $1.2-1.8$ & 5 \\
& & $(6,7,8,9,10)$ & 11 \\
Black carbon & 1.8 & $\begin{array}{l}1.0^{* *}-2.0 \\
(10,11)\end{array}$ & 12 \\
Dust & 2.65 & $2.5-2.75$ & 12 \\
Water & 0.9971 & - & 14 \\
\hline
\end{tabular}

* Weighted density from $20 \%$ wt levoglucosan, $40 \%$ wt succinic acid, and $40 \%$

Suwannee River reference fulvic acid (Svenningsson et al., 2006).

** Bond and Bergstrom state that a density of 1.0 has never been observed.

1 Tang (1996), 2 Weast (1985), 3 Köpke et al. (1997), 4 Hess et al. (1998),

5 Svenningsson et al. (2006), 6 Turpin and Lim (2001), 7 Dick et al. (2000),

8 Hallquist et al. (2009), 9 Dinar et al. (2006), 10 Ganguly et al. (2009),

11 Bond and Bergstrom (2006), 12 McConnell (2009),

13 Wagner et al. (2009) and references therein,

14 Tang and Munkelwitz (1994).

mixing state for the calculation of the effective refractive index of these species causes only a moderate change in RRI, $\sim 0.01-0.02$.

Table 3 lists molecular masses and specific densities of the model species, and we notice that the specific densities for $\mathrm{OC}$ and $\mathrm{BC}$ cover a large range over different studies. Table 4 presents an overview of RI values for aerosol dry components currently found in the literature. The variation of RI with wavelength has been estimated from published values when measurements for that specific wavelength were not available. Also, a wide range of RI values can be found here for OC, depending on its source: clean continental sources are associated with lower RI (e.g., Kanakidou et al., 2005), while pollution and biomass burning are associated with higher values ("brown carbon"; e.g., Dinar et al., 2008). For ammonium nitrate, most studies list a real refractive index (RRI) between 1.56 and 1.60 (e.g., Stelson, 1990), which is used in our study (Table 4), but sometimes a much lower RRI of 1.42 is used (e.g., Weast, 1987).

\subsubsection{Minimization procedure}

Modeled aerosol optical properties and size distribution are compared to observations from the AERONET Sun-sky radiometer, an optical, ground-based aerosol monitoring station located at Cabauw during May 2008. AERONET version 2, level 2.0 (L2.0) inversions are quality assured, and include SSA and RI when AOT >0.4. For the period under study at Cabauw, the AOT is generally smaller than 0.4. Whenever L2.0 AOT and size distribution are available but L2.0 SSA and RI are not, SSA and RI are taken from the corresponding L1.5 retrievals (Dubovik and King, 2000; cloud screened but not quality assured, Smirnov et al., 2000) 
to improve data coverage to 66 points. This effectively applies the AERONET L2.0 criteria to all parameters, except AOT $>0.4$ for SSA and RI. In this study, we refer to this data set as L2*. In addition, we consider a data set of all L1.5 inversions in Cabauw in May 2008, amounting to 132 data points. We note that the L1.5 data set also includes retrievals from measurements containing fewer scattering angles - for example, when a portion of the angular scan is affected by cloud contamination or when the solar zenith angle is relatively low, e.g., between 40 and $50^{\circ}$. For a complete overview of the differences between L1.5 and L2.0, the reader is referred to Holben et al. (2006). The results of our study enable a comparison of the quality and consistency of both data sets, L2* and L1.5, required for an accurate optimization of aerosol physical and chemical properties.

Parameters used in our study are AOT, SSA and complex refractive index data at four wavelengths $(\lambda=440,676$, 870 and $1020 \mathrm{~nm}$ ), the volume size distribution resolved in 22 size bins between 0.05 and $15 \mu \mathrm{m}$, and the aerosol spherical fraction (Table 2). The model size distribution is rebinned to the AERONET resolution before comparison. The AERONET retrieval assumes that aerosols are homogeneous, internally mixed particles with a single wavelengthdependent RI. However, aerosol RI is often size dependent (e.g., Benko et al., 2009), and our method assumes a bimodal lognormal size distribution with homogeneous composition (and thus a single RI) in each individual mode. In the present study the median absolute difference of RRI between both modes is generally very small (0.01), but it can occasionally be significant.

The uncertainties $\left(\boldsymbol{E}_{\boldsymbol{y}}\right)$ used in our model can be found in Table 2. The uncertainty in AERONET AOT is 0.01 (Eck et al., 1999). The uncertainties in the inversion parameters are derived from Dubovik et al. (2000) and pertain to the general AERONET performance. The uncertainties in RI and SSA are larger for low AOT $(<0.2)$ and low solar zenith angles (Holben et al., 2006; Torres et al., 2014). We remark that the expressions for uncertainties in Table 2 may lead to underestimation when applied to conditions with very low AOT and solar zenith angles, as well as to dust events. The uncertainty estimates presented here from Dubovik et al. (2000) are for weakly absorbing aerosols. The uncertainty in RRI may be larger under strongly absorbing conditions. For fine-modedominated aerosols, the AOT strongly decreases with wavelength, leading to larger uncertainties at longer wavelengths, especially for SSA. Finally, we note that the AERONET retrieval algorithm places constraints on the spectral variability of the complex refractive index, which may lead to additional uncertainty. Dubovik et al. (2000) state that the uncertainty in the AERONET volume distribution is $15 \%$ between 0.1 and $7 \mu \mathrm{m}$, increasing up to $100 \%$ at the distribution edges. We have set the uncertainties of the three outlying bins below 0.1 and above $7 \mu \mathrm{m}$ to 30,60 and $100 \%$, respectively. Further, because the uncertainty in the aerosol spherical fraction is not known, we arbitrarily assumed this to be $25 \%$.
The AERONET spherical fraction is used when the (440$870 \mathrm{~nm}$ ) Angström exponent is $<1.2$ and the AOT is $>0.1$ (Holben et al., 2006); otherwise the particles are assumed to be spherical. We note that the optimization does not appear to be sensitive to the magnitude of the uncertainties of the smallest and largest size bins and of the aerosol spherical fraction. The column effective RH is used both as an initial guess $(\boldsymbol{x})$ to calculate aerosol water uptake, as well as a parameter $\left(\mathrm{RH}_{\text {prior }}\right.$, in $\left.\boldsymbol{y}\right)$ that is used in the optimization. It can be adjusted by the model if this leads to a better fit with the AERONET aerosol parameters, but this will contribute to the cost function. The variance of the RH in the column is used as an uncertainty estimate, and is generally on the order of 0.1 (i.e., $10 \%$ ).

A cost function $\phi(x)$ quantifies the total difference between modeled $(F(\boldsymbol{x}))$ and observed $(\boldsymbol{y})$ aerosol parameters:

$\phi(x)=\sum_{i=1}^{N}\left(\frac{F(\boldsymbol{x})-\boldsymbol{y}}{\boldsymbol{w} \boldsymbol{E}_{y}}\right)^{2}$.

The difference between modeled and observed aerosol parameters is weighted by the uncertainties in $\boldsymbol{y}$ together with a weighting factor, $\boldsymbol{w}$, that considers interdependency of the variables, and then summed over $N$, the number of parameters in $\boldsymbol{y}$.

The routine searching for the minimum of the cost function is known as "amoeba" (Nelder and Mead, 1965). It uses a simplex based on the logarithm of the model parameters (i.e., mass concentrations of the components in each mode, the number concentration and standard deviation of the lognormal distribution of each mode and the RH; Table 1). Amoeba finds a minimum on nearly all parameter spaces, but convergence does not always result in the absolute minimum. The probability of finding the latter is greatly improved by restarting amoeba on a previously found minimum until the cost function converges.

\subsection{IMPACT observations}

In order to assess the representativity of the optimized aerosol composition, the model results are compared to surface aerosol measurements from the IMPACT campaign (Kulmala et al., 2011; Mensah et al., 2012), carried out at Cabauw in the Netherlands as part of the European Integrated Project on Aerosol Cloud Climate and Air Quality interactions (EUCAARI, Kulmala et al., 2009, 2011). The Cabauw Experimental Site for Atmospheric Research (CESAR, Russchenberg et al., 2005; http://www.cesar-observatory.nl; $51.97^{\circ} \mathrm{N}, 4.93^{\circ} \mathrm{E},-0.7 \mathrm{~m}$ a.s.1.) is located in a typical rural area in the central Netherlands with nearly flat orography in all directions. This area is also well representative of central Europe. During IMPACT, aerosol and cloud data were gathered near the $213 \mathrm{~m}$ high Cabauw Tower. Balloon sounding and helicopter and aircraft measurements from a wider area around Cabauw are also available. A direct comparison of 
Table 4. Refractive indices for four different wavelengths (440, 676, 870 and $1020 \mathrm{~nm})$ presented with a range found in the literature. When no imaginary part (italic) is listed, it is assumed to be zero.

\begin{tabular}{llllll}
\hline Compound & $440 \mathrm{~nm}$ & $676 \mathrm{~nm}$ & $870 \mathrm{~nm}$ & $1020 \mathrm{~nm}$ & Range \\
\hline$\left(\mathrm{NH}_{4}\right)_{2} \mathrm{SO}_{4}$ & 1.535 & 1.525 & 1.52 & 1.52 & - \\
$\mathrm{NH}_{4} \mathrm{HSO}_{4}$ & 1.48 & 1.47 & 1.465 & 1.465 & - \\
$\mathrm{H}_{2} \mathrm{SO}_{4}(97 \%$ wt) & 1.43 & 1.42 & 1.415 & 1.41 & $1.41-1.43(2,3,4)$ \\
$\mathrm{NaCl}$ & 1.56 & 1.546 & 1.534 & 1.532 & $1.49-1.55(5,6,1)$ \\
$\mathrm{NH}_{4} \mathrm{NO}_{3}$ & 1.56 & 1.545 & 1.54 & 1.535 & $1.41-1.60(7,8,9,10)$ \\
Organics & $1.57-1.5 e-2 i$ & $1.55-5 e-3 i$ & $1.54-3 e-3 i$ & $1.535-3 e-3 i$ & $1.43-1.652 e-3-0.1 i(11,12,13)$ \\
Black carbon & $1.85-0.71 i$ & $1.85-0.71 i$ & $1.85-0.71 i$ & $1.85-0.71 i$ & $1.50-2.00 .44^{*}-1.0 i(14,16,17,18,19)$ \\
Dust & $1.54-8 e-3 i$ & $1.52-5 e-3 i$ & $1.51-3 e-3 i$ & $1.51-3 e-3 i$ & $1.52-1.581 e-3-1 e-2 i(20,21,22,23)$ \\
Water & 1.344 & 1.331 & 1.324 & 1.321 & $-20,21$ \\
\hline
\end{tabular}

* Bond and Bergstrom argue that the low IRI (0.44) value for BC (from the OPAC database) should be discarded.

1 Toon et al. (1976), 2 Stelson (1990), 3 Benko et al. (2009), 4 Hess et al. (1998), 5 Shettle and Fenn (1979), 6 Tang (1996), 7 Weast (1987) from Benko et al. (2009) (550-589 nm),

8 Richardson and Hightower (1987) (633 nm), 9 Tang (1996), 10 Weast (1985), 11 Köpke et al. (1997), 12 Dinar et al. (2008), 13 Hoffer et al. (2006), 14 Horvath (1998),

15 Stier et al. (2007), 16 Bond and Bergstrom (2006), 17 Chang and Charalampopoulos (1990), 18 Janzen (1979), 19 Schuster et al. (2005), 20 Kinne et al. (2003),

21 Sokolik et al. (1993), 22 Wagner et al. (2012), 23 Kandler et al. (2011) (532 nm, Cape Verde), 24 Segelstein (1981).

the optimized size distribution with surface measurements is not possible due to technical problems with the scanning mobility particle sizer (SMPS, a modified TSI Inc. model 3034) and the CPC (TSI Inc. model 3762). We note that aerosol hygroscopicity measurements $(90 \% \mathrm{RH}$ growth factors) from a hygroscopicity tandem differential mobility analyzer (H-TDMA) are available for particle radii $\mathrm{D}_{p} \leq 165 \mathrm{~nm}$ (http://ebas.nilu.no/), but their quality is unknown as the data are as yet unpublished.

\subsubsection{Specific model assumptions for Cabauw during May 2008}

The first two weeks of May 2008 were characterized by highpressure, relatively fair weather and a steady easterly wind in the lower atmosphere throughout most of the period. During the second half of the month the weather was more unsettled, with cloudy and rainy periods (e.g., Roelofs et al., 2010; Hamburger et al., 2011), and as a result AERONET observations are relatively sparse. Therefore we focus our analysis on 1-14 May. We assume that the aerosol is homogeneously distributed in a layer of $2 \mathrm{~km}$ depth at the surface. The "effective" RH in this layer is derived from radiosonde measurements by means of averaging water vapor pressure and temperature in this layer. Radiosonde measurements are available three times a day during the campaign, around 05:00, 10:00 and 16:00 UTC. The columnar RH is time-interpolated to the AERONET data available.

We remark that sea salt and dust have been omitted from this study. Cabauw is located only $50 \mathrm{~km}$ from the coast, but the first half of May is dominated by easterly winds and therefore a strong continental influence. Further, observed $\mathrm{Cl}^{-}$concentrations are very low $\left(\ll 1 \mu \mathrm{g} \mathrm{m}^{-3}\right)$. Traces of Sahara dust were present over the Cabauw region only on 4 May (Roelofs et al., 2010). To reduce the number of parameters in the optimization we assumed specific ammonium: sulfate and nitrate: sulfate ratios, based on Gysel et al. (2007). The ammonium to sulfate mass ratio that corresponds best to surface measurements is 1.8 . Surface observa- tions of ammonium nitrate during May 2008 correlate well $\left(R^{2}=0.71\right)$ with that of sulfate; the mass ratio of ammonium nitrate to sulfate is 1.3 .

\subsubsection{AERONET}

The optimization procedure uses AERONET retrievals for Cabauw. Figure 2 shows AERONET AOT, the Ångström exponent, boundary layer RH, RRI, SSA and IRI for the first half of May 2008. Between 6 and 12 May, dry continental air was advected from the east. Figure $2 \mathrm{a}$ shows that AOT $(676 \mathrm{~nm})$ is generally between 0.05 and 0.25 (the mean and standard deviation are $0.13 \pm 0.05$ and $0.13 \pm 0.04$ for L1.5 and L2* AERONET data, respectively). The Ångström exponent generally exceeds $1(1.48 \pm 0.26$ and $1.51 \pm 0.24$ for level 1.5 and $2^{*}$, respectively), indicating that the fine-mode fraction dominates the aerosol optical properties. During daytime a well-mixed boundary layer was formed between 0 and $2 \mathrm{~km}$ altitude above the surface. The atmosphere is relatively dry, with RH between 30 and $70 \%(48 \pm 10 \%)$ except for the first three days (Fig. 2b), and the variability during a day is on the order of $10-20 \%$. AOT displays a distinct daily variability with a minimum around noon on days when RH is relatively high (e.g., 6-8 May). On the driest days, e.g., 9-11 May, AOT strongly increases during the day. The RRI ranges between the AERONET lower and upper bounds of 1.33 and 1.60 (the mean and standard deviation for RRI $(676 \mathrm{~nm})$ are $1.46 \pm 0.06$ and $1.47 \pm 0.05$ for level 1.5 and $2^{*}$, respectively). It is highly variable, even during a single day (e.g., 9 and 10 May) and appears to be only weakly related to $\mathrm{RH}$. Single-scattering albedo $(676 \mathrm{~nm})$ varies from 0.8 to near $1.00(0.88 \pm 0.04$ and $0.88 \pm 0.03$ for L1.5 and L2*, respectively) and is lowest on 11 and 12 May $(\sim 0.82-0.87)$ (Fig. 2c). The SSA is strongly correlated with IRI $\left(R^{2}=0.83\right.$ and 0.84 for L1.5 and L2* data, respectively). 


\subsubsection{Aerosol chemical composition}

Surface concentrations of inorganic aerosol species $\mathrm{NO}_{3}^{-}$, $\mathrm{SO}_{4}^{2-}, \mathrm{NH}_{4}^{+}, \mathrm{Na}^{+}$and $\mathrm{Cl}^{-}$were measured with a MARGA instrument (Monitor for Aerosols and Gases, Applikon Analytical BV; ten Brink et al., 2007; Thomas et al., 2009), with an hourly resolution and a measurement error smaller than $10 \%$ (Schaap et al., 2011, and references therein). Black carbon mass concentrations are measured with a multi-angle absorption photometer (MAAP; Thermo Scientific model 5012; Petzold et al., 2005) with a resolution of 5 min and uncertainty of $12 \%$ (Petzold and Schönlinner, 2004). Aerosol organic concentrations were measured with an Aerodyne aerosol mass spectrometer (HR-ToF-AMS) (Jülich ICG-2; Canagaratna et al., 2007) with a 5 min time resolution from an inlet at $60 \mathrm{~m}$ altitude (Mensah et al., 2012). Measured AMS PM1 mass concentrations for inorganic and organic ambient aerosol species are reproducibly accurate to approximately $\pm 25 \%$ (Canagaratna et al., 2007).

We note that measured organic masses are effectively $\mathrm{PM}_{1}$ ( $100 \%$ transmission in range $70-500 \mathrm{~nm}$ and $50 \%$ for particles with $1 \mu \mathrm{m}$ diameter). To compare these with the optimized organic mass, which is essentially $\mathrm{PM}_{10}$, we scaled the AMS measurements to $\mathrm{PM}_{10}$ based on the observed sulfate masses from MARGA and the AMS. This implies that sulfate and organics are distributed similarly over aerosol size, which is a reasonable assumption because a significant fraction of secondary organic as well as inorganic (sulfate) aerosol matter formed in the gas phase deposits onto the fine mode (Kulmala et al., 2004; Kanakidou et al., 2005; Hallquist et al., 2009).

\section{Results}

The refractive index is a crucial parameter in the optimization of the aerosol chemical composition. Figure 3 shows a comparison between the optimized RRI and the AERONET retrieved values. Between the values 1.40 and 1.56 the discrepancies between our results and AERONET are generally within the uncertainty range (i.e., $0.025-0.05$, Table 2 ). In several cases, however, especially for the level 1.5 data, the AERONET RRI is less than 1.40. As can be seen in Fig. 4, which compares RRI and RH, the corresponding columnar $\mathrm{RH}$ is relatively low, ranging between 38 and $65 \%$. The AERONET RRI has a very low correlation with the columnar RH $\left(R^{2}=0.14,0.14\right.$ and 0.36 for the L1.5, L2* and non-suspect data, respectively), suggesting large variations in aerosol composition or relatively large uncertainties in the AERONET RRI. Our model cannot simulate the lowest RRI values at the observed columnar RH with the current choice of aerosol compounds. These low RRI values also cannot directly be attributed to cloud contamination of the AERONET retrievals (e.g., de Meij et al., 2007; Schaap et al., 2009), because close inspection of the CAELI (CESAR Water Vapour,
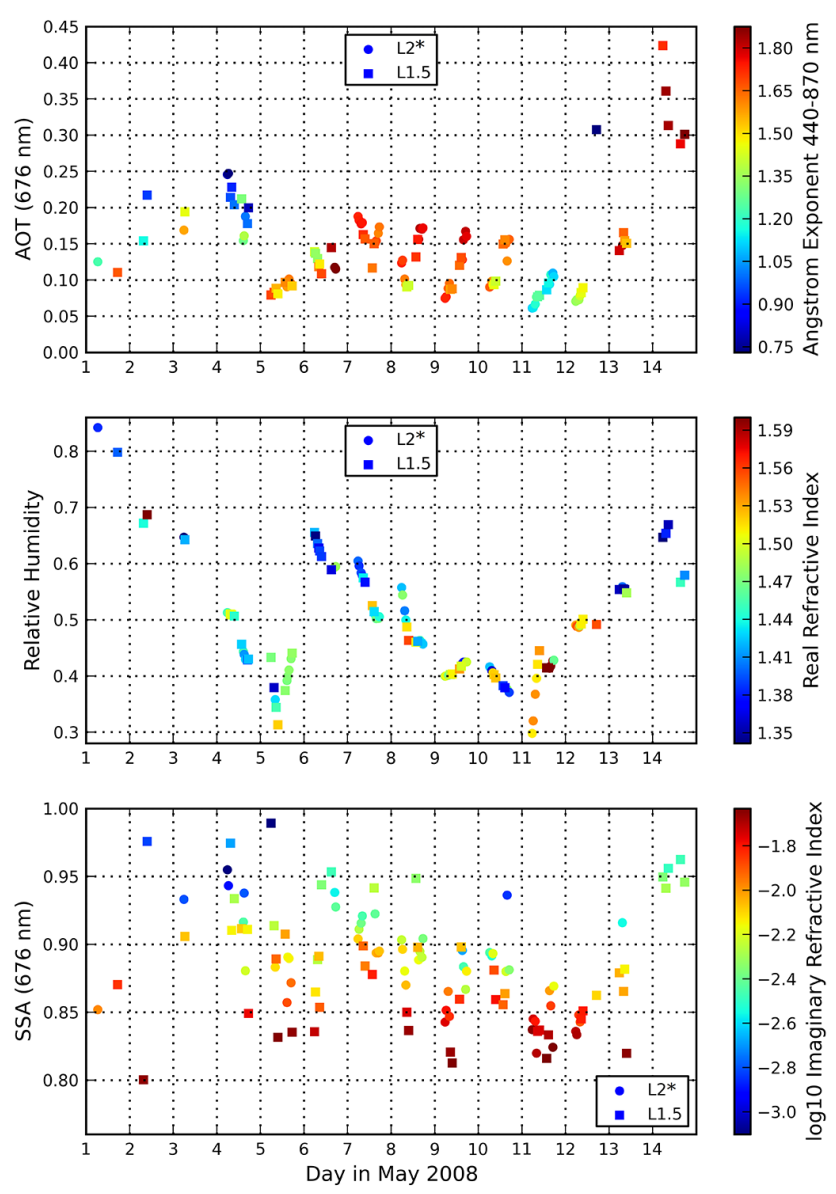

Figure 2. AERONET almucantar retrieval data (level 1.5: squares; L2*: dots) during the first 14 days of May 2008 at the Cabauw Tower. (a) Aerosol optical thickness (AOT) color-coded with values of the Ångström exponent (440-870 nm), (b) the columnar relative humidity from balloon soundings between 0 and $2 \mathrm{~km}$ colorcoded with the AERONET real part of the refractive index, and (c) AERONET single-scattering albedo (SSA) color-coded with the (base 10 logarithm) imaginary part of the refractive index.

Aerosol and Cloud Lidar; Apituley et al., 2009) data showed that low RRI values seem to occur both on clear days (e.g., 7 and 8 May) as well as on days with a slight lidar backscatter signal between 8 and $12 \mathrm{~km}$ altitude (most other days). Most of the discrepancies relate to L1.5 data and not to the L2* data, which may reflect the difference in accuracy. Some discrepancies remain in the $\mathrm{L} 2{ }^{*}$ data, while several $\mathrm{L} 1.5$ data points yield reasonable results. We have labeled "suspect" those results associated with AERONET RRI values outside the range that our model can represent (at the effective $\mathrm{RH})$, and results with a cost function larger than 10 . The suspect data represent about $40 \%$ of the data considered. Table 5 presents the (squared) Pearson linear correlation coefficients between optimized and AERONET values of the RRI, IRI, AOT, SSA, total binned volume (VOL), aerosol spherical fraction (SPH) and RH. Generally, excellent agreement 
Table 5. Squared Pearson correlation coefficients $\left(R^{2}\right)$ between model computed (optimized) values and AERONET inversions of the real and imaginary part of the refractive index (RRI and IRI), aerosol optical thickness (AOT), single-scattering albedo (SSA) at four wavelengths, the sum of the binned AERONET volume distribution (VOL), AERONET spherical fraction (SPH) and columnar relative humidity (RH) derived from radiosonde measurements for the non-suspect data, L1.5 and L2* data (latter two between parentheses) during the first 14 days of May.

\begin{tabular}{cllll}
\hline Correlation $\left(R^{2}\right)$ & $440 \mathrm{~nm}$ & $676 \mathrm{~nm}$ & $870 \mathrm{~nm}$ & $1020 \mathrm{~nm}$ \\
\hline RRI & $0.80(0.78,0.82)$ & $0.94(0.81,0.89)$ & $0.90(0.84,0.91)$ & $0.84(0.83,0.89)$ \\
IRI & $0.79(0.79,0.71)$ & $0.98(0.98,0.98)$ & $0.98(0.98,0.98)$ & $0.97(0.96,0.96)$ \\
AOT & $1.00(0.99,1.00)$ & $1.00(0.99,1.00)$ & $0.99(0.99,0.99)$ & $0.99(0.99,0.99)$ \\
SSA & $0.93(0.84,0.85)$ & $0.98(0.98,0.98)$ & $0.98(0.97,0.96)$ & $0.98(0.97,0.96)$ \\
VOL & $0.99(0.85,0.93)$ & & & \\
SPH & $1.00(1.00,1.00)$ & & & \\
RH & $1.00(0.99,0.99)$ & & & \\
\hline
\end{tabular}

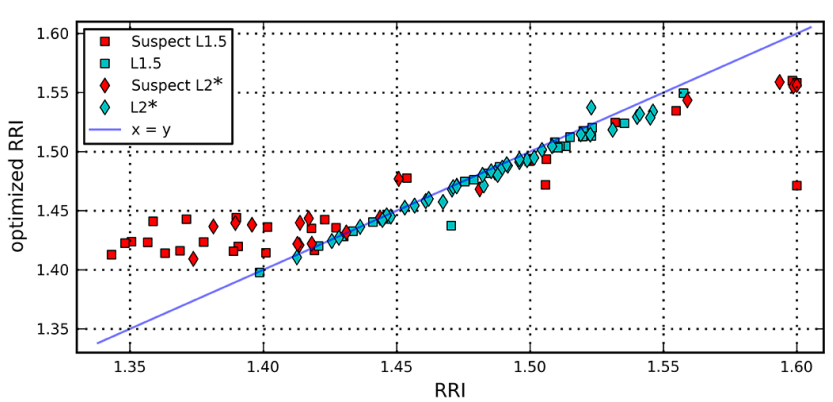

Figure 3. Scatterplot of model computed (optimized) and AERONET level 1.5 (squares) and L2* (diamonds) real refractive index (RRI) data averaged over four wavelengths. Model results have been marked "suspect" (red) when the AERONET refractive index is outside the range that our model can simulate and/or when the cost function is larger than 10 . The blue line shows the $1: 1$ ratio.

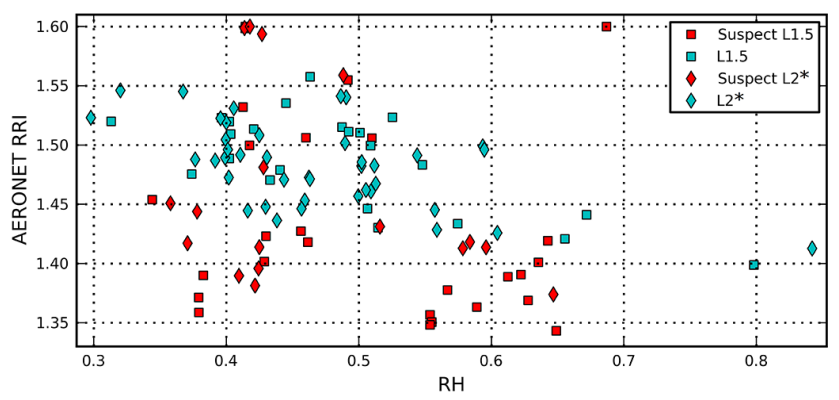

Figure 4. Scatterplot of the column effective relative humidity (RH) and the AERONET real refractive index (RRI) for level 1.5 data (squares) and L2* data (diamonds). The AERONET data that have been labeled "suspect" are presented in red.

is found for most parameters. It should be noted that in our model, the RI tends to show a stronger increase near smaller wavelengths (due to our choice of RI of the individual compounds), leading to larger discrepancies for RI and SSA at $440 \mathrm{~nm}$ than at longer wavelengths. The correlation between

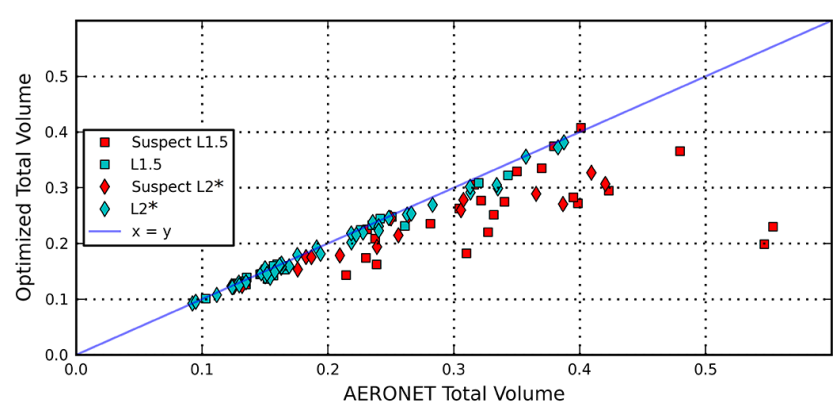

Figure 5. Scatterplot of model computed (optimized) and AERONET total volume (level 1.5: squares, L2*: diamonds). AERONET data that have been classified as suspect have been marked in red. The blue line shows the $1: 1$ ratio.

AERONET RRI and RH is smaller at $440 \mathrm{~nm}$ than at longer wavelengths, suggesting larger uncertainties at the shorter wavelengths. This is consistent with the results of Torres et al. (2012) for urban aerosol. We also note that we did not find a significant correlation between the AERONET SSA and the fine-mode volume median radius.

Figure 5 shows a comparison of the optimized and AERONET total aerosol volume. The agreement is very good for non-suspect data, but for suspect data the model calculates substantially smaller aerosol volumes, mostly associated with discrepancies between modeled and observed RRI. The average AERONET (non-suspect) and modeled (optimized) volume size distributions during 1-14 May are shown in Fig. 6. It can be seen that the AERONET coarse mode contains two weak maxima, and is therefore generally wider than the optimized (single) coarse mode.

We note that technical problems with the SMPS and CPC during the first two weeks of IMPACT hamper a direct comparison of the size distribution with surface measurements. The modeled column average number concentrations are generally between $800-3000 \mathrm{~cm}^{-3}$ during 1 to 10 May, approximately $1200 \mathrm{~cm}^{-3}$ on $11-12$ May and increasing to $4000 \mathrm{~cm}^{-3}$ on 14 May. They are of the same 
Table 6. Mean (column-average) modeled $\left(\mu_{\text {mod }}\right)$ and mean observed $\left(\mu_{\mathrm{obs}}\right)$ (near-surface) mass concentration $\left(\mu \mathrm{g} \mathrm{m}^{-3}\right)$ together with corresponding standard deviations $(\sigma)$, modeled and observed medians $\left(\operatorname{med}_{\bmod }\right.$ and $\left.\operatorname{med}_{\mathrm{obs}}\right)$ and mean absolute gross error $(\mathrm{MAGE})$ for the non-suspect (N-S) data, L1.5 and the L2* data during the first half of May 2008. NB: NA is given when there are no observational data available.

\begin{tabular}{|c|c|c|c|c|c|c|}
\hline \multicolumn{2}{|c|}{ Conc $\left[\mu \mathrm{g} \mathrm{m}^{-3}\right]$} & \multirow{2}{*}{$\begin{array}{l}\mu_{\mathrm{mod}} \pm \sigma_{\mathrm{mod}} \\
30.3 \pm 8.40\end{array}$} & \multirow{2}{*}{$\frac{\mu_{\mathrm{obs}} \pm \sigma_{\mathrm{obs}}}{31.3 \pm 11.0}$} & \multirow{2}{*}{$\begin{array}{l}\operatorname{med}_{\text {mod }} \\
27.8\end{array}$} & \multirow{2}{*}{$\begin{array}{l}\operatorname{med}_{\mathrm{obs}} \\
30.1\end{array}$} & \multirow{2}{*}{$\begin{array}{l}\text { MAGE } \\
9.99\end{array}$} \\
\hline Dry mass & $\mathrm{N}-\mathrm{S}$ & & & & & \\
\hline & L1.5 & $36.1 \pm 28.2$ & $30.2 \pm 11.2$ & 30.4 & 28.5 & 13.6 \\
\hline & $\mathrm{L} 2 *$ & $32.3 \pm 9.66$ & $28.6 \pm 12.2$ & 29.4 & 28.4 & 12.1 \\
\hline \multirow[t]{3}{*}{$\mathrm{SO} 4^{2-}$} & $\mathrm{N}-\mathrm{S}$ & $5.51 \pm 3.11$ & $4.42 \pm 1.38$ & 4.92 & 4.84 & 2.87 \\
\hline & $\mathrm{L} 1.5$ & $7.11 \pm 4.57$ & $4.37 \pm 1.38$ & 6.67 & 4.69 & 4.37 \\
\hline & $\mathrm{L} 2 *$ & $6.99 \pm 4.21$ & $4.24 \pm 1.64$ & 6.62 & 4.44 & 4.01 \\
\hline \multirow[t]{3}{*}{$\mathrm{NH}^{4+}$} & $\mathrm{N}-\mathrm{S}$ & $4.03 \pm 2.27$ & $3.34 \pm 1.55$ & 3.59 & 3.05 & 2.19 \\
\hline & $\mathrm{L} 1.5$ & $5.20 \pm 3.34$ & $3.35 \pm 1.57$ & 4.87 & 3.23 & 2.94 \\
\hline & $\mathrm{L} 2^{*}$ & $5.11 \pm 3.08$ & $3.11 \pm 1.66$ & 4.84 & 3.03 & 2.92 \\
\hline \multirow[t]{3}{*}{$\mathrm{NO}^{3-}$} & $\mathrm{N}-\mathrm{S}$ & $7.44 \pm 4.20$ & $7.76 \pm 3.64$ & 6.63 & 7.71 & 3.73 \\
\hline & $\mathrm{L} 1.5$ & $9.60 \pm 6.17$ & $7.48 \pm 4.35$ & 9.00 & 7.04 & 4.75 \\
\hline & $\mathrm{L} 2 *$ & $9.44 \pm 5.68$ & $7.00 \pm 4.07$ & 8.94 & 5.02 & 4.79 \\
\hline \multirow[t]{3}{*}{$\mathrm{OC}$} & $\mathrm{N}-\mathrm{S}$ & $12.6 \pm 7.43$ & $14.8 \pm 5.35$ & 13.4 & 14.6 & 6.77 \\
\hline & $\mathrm{L} 1.5$ & $13.3 \pm 27.5$ & $13.9 \pm 5.37$ & 10.4 & 14.1 & 13.0 \\
\hline & $\mathrm{L} 2 *$ & $9.98 \pm 9.68$ & $13.0 \pm 6.22$ & 8.92 & 14.0 & 9.09 \\
\hline \multirow[t]{3}{*}{$\mathrm{BC}$} & $\mathrm{N}-\mathrm{S}$ & $0.73 \pm 0.32$ & $0.88 \pm 0.46$ & 0.69 & 0.75 & 0.41 \\
\hline & L1.5 & $0.75 \pm 0.34$ & $0.89 \pm 0.49$ & 0.72 & 0.74 & 0.48 \\
\hline & $\mathrm{L} 2 *$ & $0.71 \pm 0.24$ & $0.83 \pm 0.49$ & 0.70 & 0.70 & 0.46 \\
\hline \multirow[t]{3}{*}{$\mathrm{H}_{2} \mathrm{O}$} & $\mathrm{N}-\mathrm{S}$ & $6.09 \pm 4.98$ & NA & 4.60 & NA & NA \\
\hline & $\mathrm{L} 1.5$ & $8.55 \pm 7.84$ & NA & 7.45 & NA & NA \\
\hline & $\mathrm{L} 2 *$ & $7.79 \pm 6.86$ & NA & 6.26 & NA & NA \\
\hline
\end{tabular}

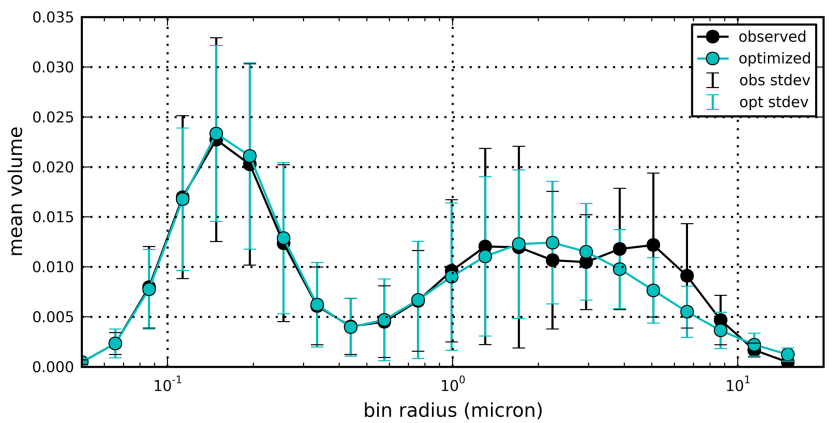

Figure 6. Average AERONET (black dots) and optimized (turquoise dots) volume distribution for the non-suspect data during 1-14 May. The bars indicate the standard deviation of the data in each bin.

magnitude as observed during aircraft measurements in the boundary layer around Cabauw: approximately $1500 \mathrm{~cm}^{-3}$ on 6 May (FAAM BAe-146, $D_{\mathrm{p}}=0.1-0.8 \mu \mathrm{m}$ ), $2500 \mathrm{~cm}^{-3}$ on 8 May (DLR Falcon 20, CCN $>10 \mathrm{~nm}$ ), 800 on 12 May and $1200 \mathrm{~cm}^{-3}$ on 13 May (FAAM BAe-146) (Hamburger et al., 2011, their Fig. 9).

Figure 7 shows computed column-average dry aerosol mass concentration and the total observed dry mass concentration at the surface, i.e., the sum of scaled organic mass concentrations from the AMS instrument, all aerosol

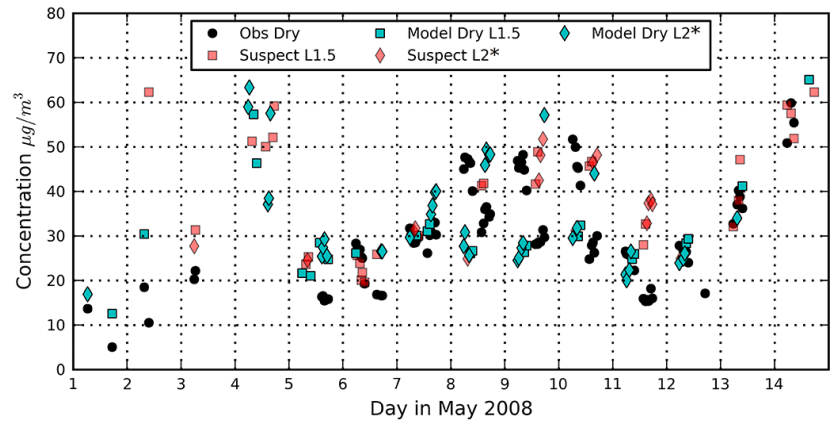

Figure 7. Time series of total $\left(\mathrm{PM}_{10}\right.$ equivalent) dry mass concentration from surface measurements (black dots), and our model results (turquoise squares and diamonds for results based on nonsuspect AERONET L1.5 data and L2* data, respectively) during the first half of May 2008 at the Cabauw Tower. Results based on AERONET data that have been labeled "suspect" are presented in red.

$\mathrm{PM}_{10}$ from the MARGA instrument and black carbon from the MAAP. Excluding the suspect values, the modeled concentrations show good agreement with the mean and variability of observed concentrations, i.e., $30.3 \pm 8.40 \mu \mathrm{g} \mathrm{m}^{-3}$ vs. $31.3 \pm 11.0 \mu \mathrm{g} \mathrm{m}^{-3}$ (normalized mean bias is $3 \%$ ). The agreement between observations and retrieval is generally best in a period of quiet, dry and sunny weather between 6 


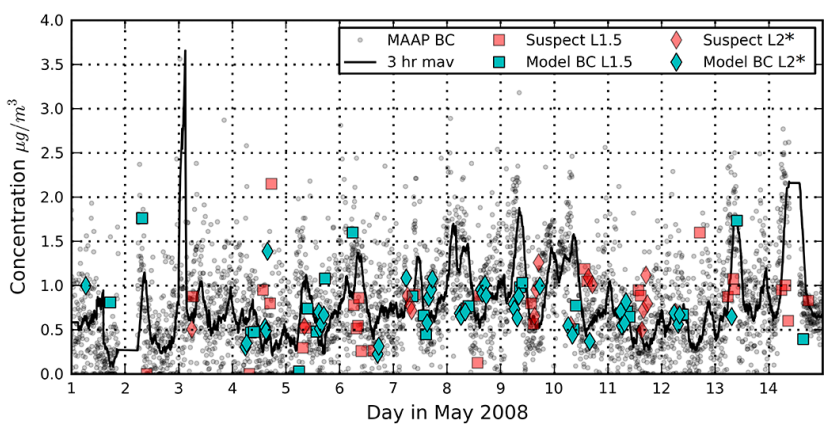

Figure 8. Time series of black carbon concentration from surface observations (multi-angle absorption photometer, black dots) with $3 \mathrm{~h}$ centered moving average (black line), and our model results (L1.5: turquoise squares; L2*: turquoise diamonds; suspect: red).

and 14 May. Measurements from the CAELI and radiosonde observations indicated that most of the aerosol and highest RH were located in a (reasonably) well-mixed boundary layer of approximately $2 \mathrm{~km}$ depth, consistent with our assumptions. Including the suspect values, the computed values and associated standard deviation are significantly larger $\left(36.1 \pm 28.2 \mu \mathrm{g} \mathrm{m}^{-3}\right)$ than observed $(30.2 \pm 11.2)$. Note, however, that this is predominately caused by a few outliers, and that the modeled and observed medians are still reasonably close (30.4 versus $28.5 \mu \mathrm{g} \mathrm{m}^{-3}$ ).

Although the daily averages of computed dry mass and the observations appear to be in reasonable agreement, for some days (e.g., 8-11 May) the daily cycle of the computed aerosol concentration is opposite to that of the surface observations, with the former showing an increase and the latter a decrease during the day. The increase in modeled dry aerosol concentration during the afternoon is associated with a large, approximately two-fold increase in AERONET AOT (e.g., 8 and 9 May), while RRI slightly increases or remains approximately equal. The discrepancy between modeled and observed variability is partly due to the different effects of boundary layer meteorology on columnar mass and on surface concentration. During the early morning hours, aerosols are trapped in a thin, stable layer near the surface. This layer will rapidly mix with the atmosphere above when heated by the sun, leading to a reduction in the aerosol concentration near the surface without changing the total column aerosol burden. Additionally, rapidly rising temperatures near the surface during the day shift the partitioning of semi-volatile gases such as ammonium nitrate and volatile organic compounds to the gas phase (Schaap et al., 2011; Aan de Brugh et al., 2012). More abundant road traffic and photochemical production of secondary aerosol during daytime may be the reason why the computed (column-average) dry mass increases in the afternoon, reflecting the strong increase of AERONET AOT.
Table 6 lists modeled (total column-average) and observed (surface) mass concentrations. The agreement between both is reasonable for the non-suspect data, i.e., within the computed standard deviations, with computed BC (bias is $-17 \%)$, OC $(-15 \%)$ and nitrate $(-4 \%)$ somewhat smaller, and sulfate $(+25 \%)$ and ammonium $(+21 \%)$ significantly larger than observed.

A comparison between optimized and measured concentrations for individual aerosol species is presented in Fig. 8 for black carbon, and in Fig. 9 for the inorganic salt ions $\left(\mathrm{SO}_{4}^{2-}, \mathrm{NH}_{4}^{+}\right.$and $\left.\mathrm{NO}_{3}^{-}\right)$and organic matter. Optimized $\mathrm{BC}$ concentrations (Fig. 8) fall within the same range as observed concentrations. On some days the observed hourly variability, represented by the black line, appears to be captured by the model (6, 13 May). A significant overestimation occurs on 4 May (to a lesser extent also on 2 May and during one measurement in the afternoon of 12 May; however these are already marked as "suspect"), when traces of Sahara dust were present over the Cabauw region (Roelofs et al., 2010). Since mineral dust is not taken into account in this study, the associated scattering and absorption is now attributed to the other compounds in our model. Nevertheless, we conclude that the optimization performs relatively well for BC, especially considering the uncertainties in AERONET SSA and IRI. For other species the comparison for the individual optimizations is less favorable. Optimization results display a relatively large variability compared to measured concentrations. As will be discussed later, RRI is a dominant parameter in the optimization, and errors in RRI lead to compensating solutions between the more hygroscopic inorganic salts and the less hygroscopic OC. Figure 10 shows daily averages of modeled and observed aerosol species. The day-today variability and the daily averaged concentrations, especially for the inorganic salts (sulfate, ammonium and nitrate), are captured reasonably well (i.e., mean bias is $5 \%$ for $\mathrm{PM}_{10}$ and black carbon, $10 \%$ for the inorganic salts and $18 \%$ for organic matter, and root-mean-squared deviations are $26 \%$ for $\mathrm{PM}_{10}$ and $35-45 \%$ for the individual compounds; Table 7). Concentrations are relatively low on 1-2, 5-7 and 11-12 May, while higher concentrations are observed and modeled between 7 and 10 and between 13 and 14 May. We note that on 11-12 May a brief period with northeasterly winds occurred, advecting relatively clean air characterized by small AOT $(\sim 0.1)$, low RH and high refractive index (RRI > 1.48, Fig. 2). Our model calculates concentrations of inorganic salts that are considerably smaller than those of the surrounding days, in good agreement with the observations.

The largest discrepancies are found on 7-9 May and later on 14 May, when our method overestimates concentrations of sulfate and ammonia but underestimates OC. This relates to days when the RI shows strong hourly variability even though RH is relatively constant. For relatively high RRI $(>1.52)$ our method calculates relatively high concentrations of OC, whereas for relatively small RRI $(<1.44)$, water and inorganic salts dominate the modeled aerosol composition. 

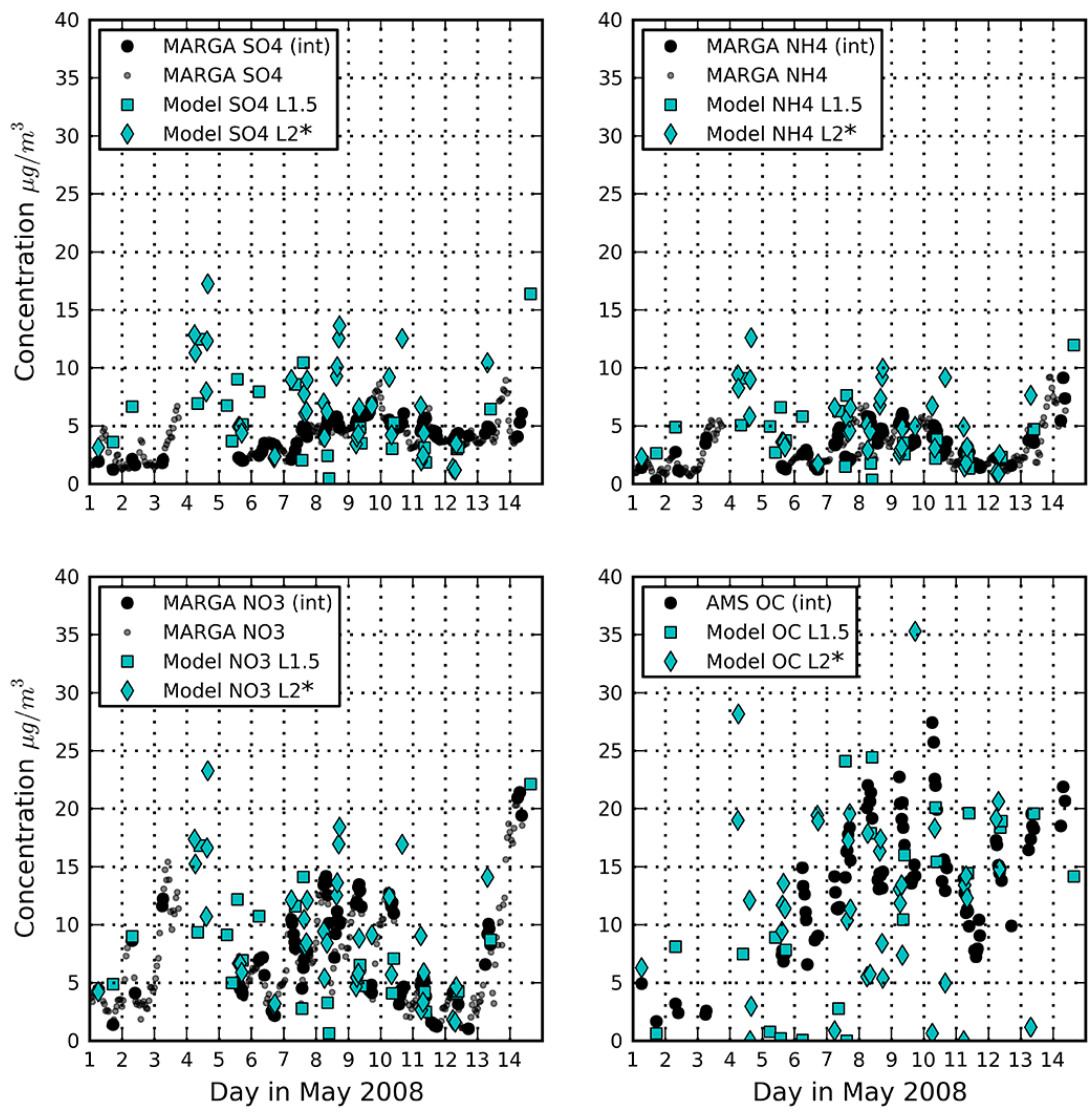

Figure 9. Inorganic salt ion concentrations, $\mathrm{SO}_{4}^{2-}$ (upper left), $\mathrm{NH}_{4}^{+}$(upper right), $\mathrm{NO}_{3}^{-}$(lower left) from surface observations of the MARGA (small grey dots), and organic matter (OC) from Jülich ICG-2 AMS (scaled to PM 10 , lower right), interpolated to AERONET times (bold black dots) and compared to the column-average model results (turquoise squares and diamonds for data based on AERONET L1.5 and L2* data, respectively). Results based on suspect AERONET data have been left out.

Table 7. Daily average mean (column-average) modeled $\left(\mu_{\text {mod }}\right)$ and observed $\left(\mu_{\mathrm{obs}}\right)$ (near-surface) mass concentration $\left(\mu \mathrm{g} \mathrm{m}^{-3}\right)$ together with corresponding standard deviations $(\sigma)$, mean and standard deviation errors in model and observations $\left(\mu_{\mathrm{er}} \pm \sigma_{\mathrm{er}}\right)$, regression slope and offset, correlation coefficient $(R)$, and root-mean-squared deviations (RMS) for non-suspect data during the first half of May 2008. Inorganic salts ("Salts") is the sum of the mass concentrations of $\mathrm{SO}_{4}, \mathrm{NH}_{4}$ and $\mathrm{NO}_{3}$ ions.

\begin{tabular}{lccccccc}
\hline Conc $\left[\mu \mathrm{g} \mathrm{m}^{-3}\right]$ & $\mu_{\mathrm{mod}} \pm \sigma_{\mathrm{mod}}$ & $\mu_{\mathrm{obs}} \pm \sigma_{\mathrm{obs}}$ & $\mu_{\mathrm{er}} \pm \sigma_{\mathrm{er}}(\operatorname{model})$ & $\mu_{\mathrm{er}} \pm \sigma_{\mathrm{er}}(\mathrm{obs})$ & regression & $R$ & RMS \\
\hline Dry mass & $29.2 \pm 6.31$ & $27.9 \pm 11.0$ & $7.8 \pm 1.7$ & $2.0 \pm 1.4$ & $y=1.37 \mathrm{x}-12.1$ & 0.78 & 7.4 \\
BC & $0.87 \pm 0.33$ & $0.92 \pm 0.39$ & $0.38 \pm 0.15$ & $0.04 \pm 0.03$ & $y=0.45 \mathrm{x}+0.53$ & 0.37 & 0.41 \\
Salts & $16.7 \pm 5.85$ & $14.1 \pm 5.53$ & $5.6 \pm 1.9$ & $0.36 \pm 0.27$ & $y=0.55 \mathrm{x}+4.81$ & 0.59 & 5.83 \\
OC & $11.6 \pm 3.64$ & $13.0 \pm 5.89$ & $6.7 \pm 2.2$ & $1.9 \pm 1.4$ & $y=1.05 \mathrm{x}+0.86$ & 0.65 & 4.70 \\
\hline
\end{tabular}

We note that the RRI of the mixture of inorganic salts is only slightly lower than that of OC (approx. 1.53, Table 4) while the assumed hygroscopicity of OC is much smaller than that of inorganic salts. Therefore, when both RRI and RH are relatively large the model computes a predominantly organic composition.

The resulting aerosol water volume fraction $\left(f V_{\text {water }}\right.$, the water volume divided by total volume) is displayed in Fig. 11. We find that at high RH (e.g., 80\%), more than half of the total aerosol volume, and therefore approximately half of the optical thickness, consists of water. The aerosol growth factor $g(\mathrm{RH})=\left(1-f V_{\text {water }}\right)^{-1 / 3}$ in this case ranges between 1.3 and 1.4. At low RH (e.g., $<40 \%$ ) the aerosol water fraction is approximately $0.1 \pm 0.08$ and $g(\mathrm{RH})$ is $1.01-1.06$. Note the strong variability of the aerosol water fraction on $7-$ 9 May, associated with the variability in AERONET RRI during each day. We calculate a scattering enhancement factor ( $f(\mathrm{RH}, \lambda)$, i.e., the ratio of the scattering coefficient at $85 \%$ RH and its dry value at $676 \mathrm{~nm}$ ) of $2.6 \pm 0.5$ during $1-14$ May. This is significantly larger than the estimate from flight 

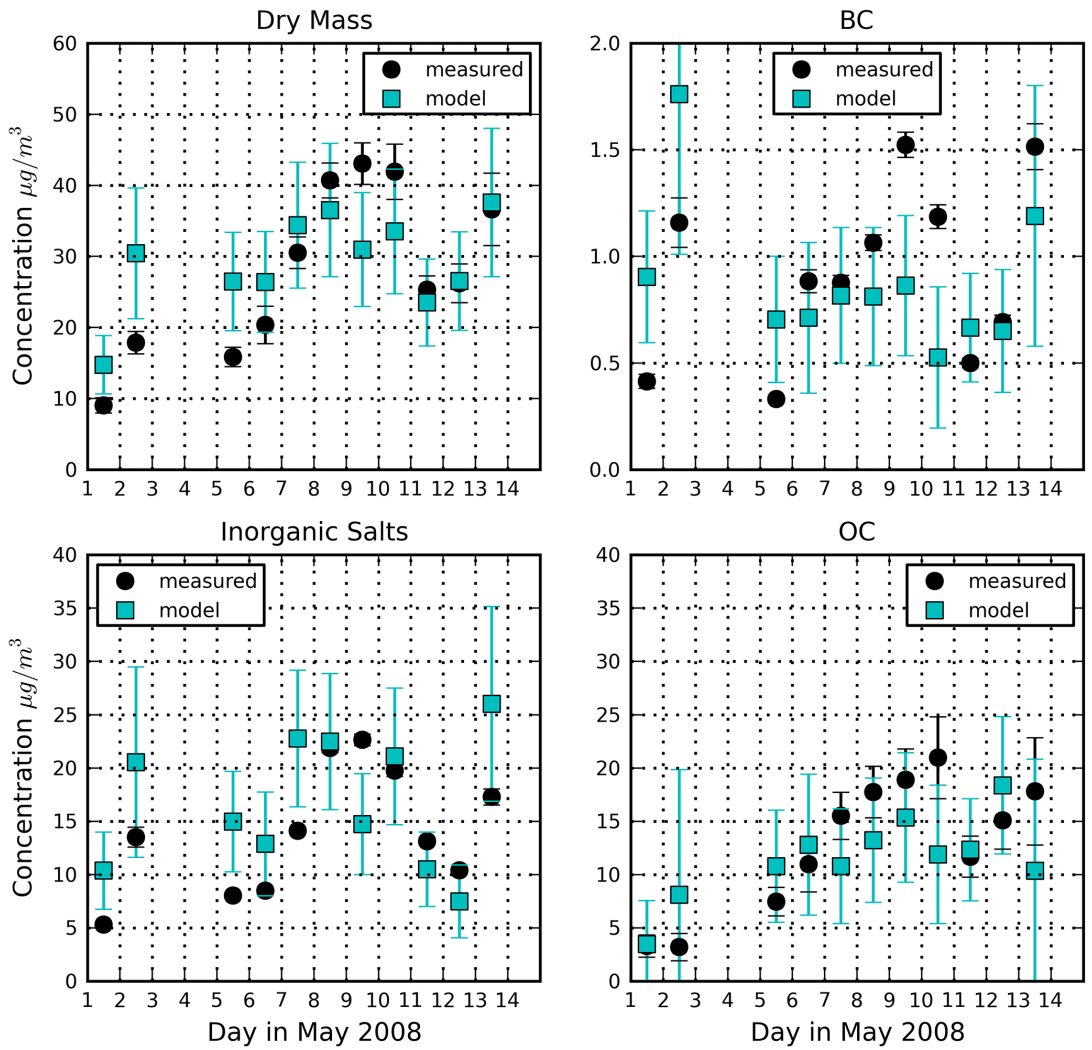

Figure 10. Modeled (turquoise squares) and observed (black dots) daily average concentrations of dry mass (PM 10 , upper left), black carbon (BC, upper right), inorganic salts (lower left) and organic matter (OC, lower right). Only the results of non-suspect AERONET data have been used in the averaging. The error bars show the uncertainty in modeled (turquoise) and observed (black) data.

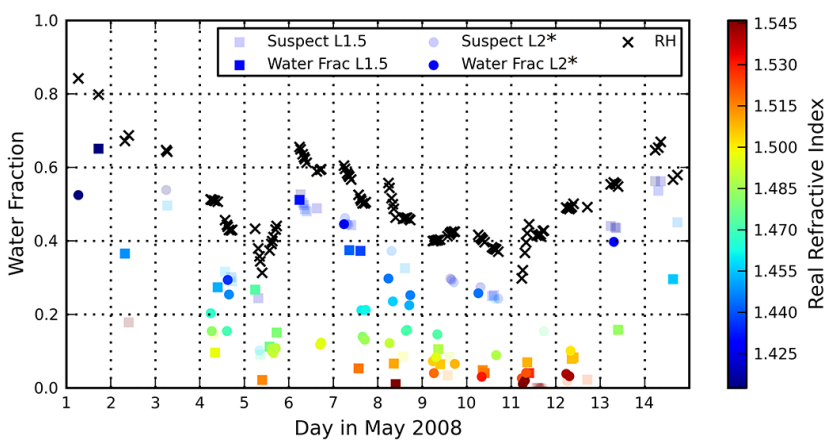

Figure 11. Calculated water volume fraction, optimized real refractive index (RRI, color-filled squares for L1.5 and dots for L2*) and columnar relative humidity (RH). Results from suspect AERONET data are opaque.

nephelometer measurements above northwestern and central Europe, with a monthly range of $f(\mathrm{RH}=85 \%, 550 \mathrm{~nm})$ between 1.23 and 1.63 (Highwood et al., 2012), but it is in relatively good agreement with surface nephelometer measurements at Cabauw for continental air in the period JuneOctober 2009, where $f(\mathrm{RH}=85 \%, 550 \mathrm{~nm})$ is $2.25 \pm 0.16$ (Zieger et al., 2013). Discrepancies between the studies are

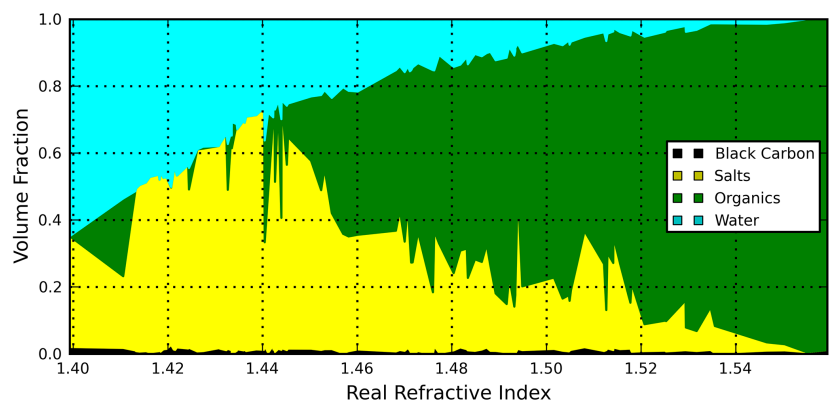

Figure 12. Volume fraction of the modeled aerosol components as a function of the optimized real refractive index during May 2008. Here, the sum of (ammonium) sulfates and ammonium nitrate has been taken into inorganic "salts", because their ratio is held constant throughout the retrieval.

likely associated with measurement inaccuracies and with different model assumptions regarding the absorption and hygroscopicity of the relatively abundant organic matter.

Figure 12 shows the relation between optimized RRI and the optimized volume fractions of the aerosol inorganic salts, $\mathrm{OC}, \mathrm{BC}$ and water. The figure shows that inorganic and organic fractions depend strongly on RRI, with decreasing 
inorganic and water volume fractions and increasing organic fractions for increasing RRI. In general the aerosol composition appears to be predominantly defined by RRI; other factors, specifically RH, may also exert significant influence (e.g., at RRI=1.41 in Fig. 12). The uncertainty associated with the optimized aerosol chemical composition strongly depends on the uncertainty of AERONET RI, the description of aerosol RI as a complex mixture of components and the optical model of scattering and absorption. Another uncertainty is associated with the depth and homogeneity of the boundary layer. Based on the model results and sensitivity tests, we tentatively estimate the uncertainties in computed volume fractions to be approximately $50 \%$ for inorganic salts, black carbon and water, and $100 \%$ for organic matter. We estimate that the uncertainty caused by the discrepancy between column-average and surface concentrations is on the order of $25 \%$ for this study. Combined, this corresponds to uncertainties of approximately 50, 100, 50, 30 and $65 \%$, for inorganic salts, OC, BC, dry mass and water in the total column aerosol mass, respectively. We expect that these uncertainties can be reduced by considering the vertical distribution of aerosols in the optimization (e.g., from a lidar) and applying our methodology to regions with higher AOT.

\section{Conclusions and discussion}

We have presented an optimization technique that derives aerosol chemical composition from remotely sensed aerosol optical thickness, single-scattering albedo, refractive index, size distribution and measurements of relative humidity. The model calculates aerosol water uptake and optical properties of a mixture of sulfate, ammonium, nitrate, black carbon and organic matter, assuming a single homogeneous layer of air, aerosol and RH. Aerosol composition and concentration are determined by minimizing the difference between modeled and AERONET aerosol properties and effective RH. The method is applied to individual measurements so that the short-term variability of the concentrations is resolved. This potentially enables study and aerosol-climate model validation of the effects of temporal variations in, for example, photochemistry, humidity and emissions on the aerosol concentration and chemical composition (Derksen et al., 2011; Aan de Brugh et al., 2012). The technique is compared to surface concentrations observed during the IMPACT measurement campaign carried out at Cabauw (the Netherlands, May 2008).

On most days the optimized column-averaged dry mass concentration agrees relatively well with surface observations from MARGA and from the Jülich ICG-2 aerosol mass spectrometer, especially during a series of dry and sunny days between 6 and 12 May. During this time most water vapor and aerosols were confined to a boundary layer of approximately $2 \mathrm{~km}$ deep, consistent with our assumptions. For the individual aerosol species, sulfate, nitrate, ammonium,
$\mathrm{BC}$ and $\mathrm{OC}$ the resulting concentrations compare relatively well with observations and reflect realistic day-to-day variability.

Nevertheless, discrepancies occur for several reasons, mainly associated with boundary layer characteristics and with RI.

1. Model results reflect columnar aerosol concentrations, while observations (e.g., MARGA, AMS) reflect surface concentrations. The daily cycle in boundary layer height affects both concentrations in different ways. In addition, the neglect of altitudinal variability of $\mathrm{RH}$, aerosol concentration and chemical composition within the boundary layer leads to further inaccuracies, especially for aerosol water uptake (e.g., Yeong et al., 2007; Bian et al., 2009; Zieger et al., 2011) and the gasparticle partitioning of ammonium nitrate (Morgan et al., 2010; Aan de Brugh et al., 2012). These discrepancies may be reduced by including information on the vertical distribution of aerosol, e.g., from lidar extinction profiles.

2. The most important parameter in the optimization of the aerosol chemical composition is the RRI. Uncertainties in modeled RRI are primarily associated with uncertainties of the RI of individual components. We found that the overall agreement between optimized and observed surface concentration of OC can only be improved by applying a somewhat larger value for RRI for OC (e.g., $1.60)$ in combination with an unrealistically small value for RRI for ammonium nitrate (1.42). On the other hand, the choice of the RI of individual compounds and the mixing rule used to calculated RI for internally mixed aerosol appears not to have a major influence on the optimized total dry aerosol mass and the amount of aerosol water, because the effect of water uptake on the aerosol RI dominates.

3. Uncertainties in AERONET RRI (0.025-0.05) lead to 10-25\% (absolute) difference in water volume fraction. AERONET RRI shows very large variations, including during the course of a single day. The correlation between RH and AERONET RRI is relatively low $\left(R^{2} \sim\right.$ 0.14 for all data, and 0.36 for non-suspect data). The optimization results display a daily variability of computed aerosol composition and hygroscopicity that may be unrealistic considering the stable and fair weather conditions in the period under research. The large variability of RRI and the low correlation between RRI and RH may be attributed to a relatively large uncertainty in RRI caused by a combination of relatively low AOT, the inclusion of low solar zenith angles for L1.5, and data with relatively high absorption in this study. Another minor inaccuracy is associated with the wavelength dependence of the AERONET RRI. For most compounds, especially OC, RI decreases with wavelength (Table 4), 
but on several occasions AERONET RI increases with wavelength, which leads to discrepancies between modeled and observed aerosol optical properties, especially at $440 \mathrm{~nm}$. Since IRI strongly increases towards the ultraviolet wavelengths for $\mathrm{OC}$, contrary to that of BC (Jacobson, 1999; Kirchstetter et al., 2004; Sun et al., 2007; and Chen and Bond, 2010), this hampers the method's ability to distinguish black carbon from absorbing organic matter ("brown carbon") (e.g., Bergstrom et al., 2007; Russell et al., 2010; Arola et al., 2011).

We conclude that the remotely sensed aerosol optical measurements from AERONET allow for a fairly accurate analysis of the daily averaged atmospheric aerosol composition, separated into the most common aerosol species (inorganic salts, BC, OC, water). The uncertainties appear too large for an accurate optimization of individual measurements, but the day-to-day variability is captured reasonably well. The study indicates that RRI has the largest information content with regard to aerosol water, while $\mathrm{RH}$ is of secondary importance. The results from level $2^{*}$ data (including L1.5 SSA and RI when AOT is <0.4) are generally more accurate than those from L1.5, although part of the L1.5 data also yields reasonable results. Therefore we conclude that despite relatively low AOT, our model performs relatively well at Cabauw, but a better performance is expected in regions with higher aerosol loading where uncertainties in SSA and RI are smaller. Our technique may be extended to global scales by using satellite remote sensing of aerosol properties (e.g., from the Polarization and Directionality of Earth Reflectances (POLDER) instrument onboard the PARASOL satellite (Hasekamp et al., 2011; Tanré et al., 2011). Accurate retrieval of the refractive index is vital for determination of column aerosol composition; in light of this, the loss of the Aerosol Polarimetry Sensor (APS) with the Glory satellite is extremely unfortunate.

Acknowledgements. We thank AERONET and Gerrit de Leeuw for their effort in establishing and maintaining the Cabauw site. We also thank the researchers conducting the measurements during the IMPACT 2008 campaign, made possible through financial support of the Sixth Framework European Integrated project on Aerosol Cloud Climate and Air Quality Interactions (EUCAARI), specifically Harry ten Brink and René Otjes (ECN) for providing the MARGA data, Th. F. Mentel and A. Kiendler-Scharr (Forschungszentrum Jülich GmbH, Germany) for the ICG-2 AMS data, Richard Rothe (KNMI) for the radiosonde data, Dave Donovan (KNMI) for the UV lidar data, and Arnoud Apituley (RIVM) for the CAELI data. We thank O. Dubovik, A. Sinyuk and B. Holben for input on the AERONET uncertainty estimates, and the anonymous reviewers for their valuable comments. We acknowledge the project and support of the European Community-Research Infrastructure Action under the FP7 "Capacities" specific program for integrating activities, ACTRIS grant agreement no. 262254.
Edited by: N. Riemer

\section{References}

Aan de Brugh, J. M. J., Henzing, J. S., Schaap, M., Morgan, W. T., van Heerwaarden, C. C., Weijers, E. P., Coe, H., and Krol, M. C.: Modelling the partitioning of ammonium nitrate in the convective boundary layer, Atmos. Chem. Phys., 12, 3005-3023, doi:10.5194/acp-12-3005-2012, 2012.

Andreae, M. O., Jones, C. D., and Cox, P. M.: Strong present day cooling implies a hot future, Nature, 435, 1187-1190, doi:10.1038/nature03671, 2005.

Apituley, A.,Wilson, K.M., Potma, C., Volten, H., and de Graaf, M.: Performance Assessment and Application of Caeli - A high performance Raman lidar for diurnal profiling of Water Vapour, Aerosols and Clouds, Proceedings of the 8th International Symposium on Tropospheric Profiling, 19-23 October 2009, Delft, The Netherlands, 2009.

Arola, A., Schuster, G., Myhre, G., Kazadzis, S., Dey, S., and Tripathi, S. N.: Inferring absorbing organic carbon content from AERONET data, Atmos. Chem. Phys., 11, 215-225, doi:10.5194/acp-11-215-2011,2011.

Bellouin, N., Boucher, O., Haywood, J., and Reddy, M. S.: Global estimate of aerosol direct radiative forcing from satellite measurements, Nature, 438, 1138-1141, doi:10.1038/nature04348, 2005.

Bellouin, N., Jones, A., Haywood, J., and Christopher, S. A.: Updated estimate of aerosol direct radiative forcing from satellite observations and comparison against the Hadley Centre climate model, J. Geophys. Res., 113, D10205, doi:10.1029/2007JD009385, 2008.

Bellouin, N., Quaas, J., Morcrette, J.-J., and Boucher, O.: Estimates of aerosol radiative forcing from the MACC re-analysis, Atmos. Chem. Phys., 13, 2045-2062, doi:10.5194/acp-13-20452013, 2013.

Benko, D., Molnár, A., and Imre, K.: Study on the size dependence of complex refractive index of atmospheric aerosol particles over Central Europe, IdỨjárás, 113, 157-175, 2009.

Bergstrom, R. W., Pilewskie, P., Russell, P. B., Redemann, J., Bond, T. C., Quinn, P. K., and Sierau, B.: Spectral absorption properties of atmospheric aerosols, Atmos. Chem. Phys., 7, 5937-5943, doi:10.5194/acp-7-5937-2007, 2007.

Bian, H., Chin, M., Rodriguez, J. M., Yu, H., Penner, J. E., and Strahan, S.: Sensitivity of aerosol optical thickness and aerosol direct radiative effect to relative humidity, Atmos. Chem. Phys., 9, 2375-2386, doi:10.5194/acp-9-2375-2009, 2009.

Bond, T. C. and Bergstrom, R. W.: Light absorption by carbonaceous particles: An investigative review, Aerosol Sci. Technol., 40, 27-67, doi:10.1080/02786820500421521, 2006.

Canagaratna, M. R., Jayne, J. T., Jimenez, J. L., Allan, J. D., Alfarra, M. R., Zhang, Q., Onasch, T. B., Drewnick, F., Coe, H., Middlebrook, A., Delia, A., Williams, L. R., Trimborn, A. M., Northway, M. J., DeCarlo, P. F., Kolb, C. E., Davidovits, P., and Worsnop, D. R.: Chemical and microphysical characterization of ambient aerosols with the aerodyne aerosol mass spectrometer, Mass Spectrom. Rev., 26, 185-222, 2007.

Chang, H. and Charalampopoulos, T. T.: Determination of the wavelength dependence of refractive indices of flame soot, Proc. R. Soc. Ldn., Ser. A, 430, 577-591, 1990. 
Chen, Y. and Bond, T. C.: Light absorption by organic carbon from wood combustion, Atmos. Chem. Phys., 10, 1773-1787, doi:10.5194/acp-10-1773-2010, 2010.

Derksen, J. W. B., Roelofs, G. J., Otjes, R., de Leeuw, G., and Röckmann, T.: Impact of ammonium nitrate chemistry on the AOT in Cabauw, the Netherlands, Atmos. Environ., 45, 5640-5646, 2011.

Deschamps, P. Y., Bréon, F. M., Leroy, M., Podaire, A., Bricaud, A., Buriez, J. C., and Seze, G.: The POLDER mission: Instrument characteristics and scientific objectives, Geosci. Remote Sens., 32, 598-615, doi:10.1109/36.297978, 1994.

Dick, W. D., Saxena, P., and McMurry, H. P.: Estimation of water uptake by organic compounds in submicron aerosols measured during the Southeastern Aerosol and Visibility Study, J. Geophys. Res., 105, 1471-1479, 2000.

Dinar, E., Mentel, T. F., and Rudich, Y.: The density of humic acids and humic like substances (HULIS) from fresh and aged wood burning and pollution aerosol particles, Atmos. Chem. Phys., 6, 5213-5224, doi:10.5194/acp-6-5213-2006, 2006.

Dinar, E., Riziq, A. A., Spindler, C., Erlick, C., Kiss, G., and Rudich, Y.: The complex refractive index of atmospheric and model humic-like substances (HULIS) retrieved by a cavity ring down aerosol spectrometer (CRD-AS), Faraday Discuss., 137, 279-295, 2008.

Dubovik, O. and King, M. D.: A flexible inversion algorithm for retrieval of aerosol optical properties from Sun and sky radiance measurements, J. Geophys. Res., 105, 20673-20696, 2000.

Dubovik, O., Smirnov, A., Holben, B. N., King, M. D., Kaufman, Y. J., Eck, T. F., and Slutsker, I.: Accuracy assessments of aerosol optical properties retrieved from AERONET sun and sky-radiance measurements, J. Geophys. Res., 105, 9791-9806, 2000.

Dubovik, O., Sinyuk, A., Lapyonok, T., Holben, B. N., Mishchenko, M., Yang, P., Eck, T. F., Volten, H., Muñoz, O., Veihelmann, B., van der Zande, W. J., Leon, J.-F., Sorokin, M., and Slutsker, I.: Application of spheroid models to account for aerosol particle nonsphericity in remote sensing of desert dust, J. Geophys. Res., 111, D11208, doi:10.1029/2005JD006619, 2006.

Eck, T. F., Holben, B. N., Reid, J. S., Dubovik, O., Smirnov, A., O'Neill, N. T., Slutsker, I., and Kinne, S.: Wavelength dependence of the optical depth of biomass burning, urban and desert dust aerosols, J. Geophys. Res., 104, 31333-31350, doi:10.1029/1999JD900923, 1999.

Erlick, C.: Effective refractive indices of water and sulfate drops containing absorbing inclusions, J. Atmos. Sci., 63, 754-763, 2006.

Erlick, C., Abbatt, J. P., and Rudich, Y.: How Different Calculations of the Refractive Index Affect Estimates of the Radiative Forcing Efficiency of Ammonium Sulfate Aerosols, J. Atmos. Sci., 68, 1845-1852, 2011.

Feingold, G.: Modeling of the first indirect effect: Analysis of measurement requirements, J. Geophys. Res., 30, 1997, doi:10.1029/2003GL017967, 2003.

Forster, P., Ramaswamy, V., Artaxo, P., Berntsen, T., Betts, R., Fahey, D. W., Haywood, J., Lean, J., Lowe, D. C., Myhre, G., Nganga, J., Prinn, R., Raga, G., Schulz, M., and van Dorland, R.: Changes in Atmospheric Constituents and in Radiative Forcing. In: Climate Change 2007: The Physical Science Basis. Contribution of WGI to the Fourth Assessment Report of the Intergovern- mental Panel on Climate Change, edited by: Solomon, S., Qin, D., Manning, M., Chen, Z., Marquis, M., Averyt, K. B., Tignor, M., and Miller, H. L., Cambridge University Press, Cambridge, UK and New York, NY, USA, Chapter 2.4, 153-180, 2007.

Ganguly, D., Ginoux, P., Ramaswamy, V., Dubovik, O., Welton, J., Reid, E. A., and Holben, B. N.: Inferring the composition and concentration of aerosols by combining AERONET and MPLNET data: Comparison with other measurements and utilization to evaluate GCM output, J. Geophys. Res., 114, D16203, doi:10.1029/2009JD011895, 2009.

Gysel, M., Crosier, J., Topping, D. O., Whitehead, J. D., Bower, K. N., Cubison, M. J., Williams, P. I., Flynn, M. J., McFiggans, G. B., and Coe, H.: Closure study between chemical composition and hygroscopic growth of aerosol particles during TORCH2, Atmos. Chem. Phys., 7, 6131-6144, doi:10.5194/acp-7-61312007, 2007.

Hallquist, M., Wenger, J. C., Baltensperger, U., Rudich, Y., Simpson, D., Claeys, M., Dommen, J., Donahue, N. M., George, C., Goldstein, A. H., Hamilton, J. F., Herrmann, H., Hoffmann, T., Iinuma, Y., Jang, M., Jenkin, M. E., Jimenez, J. L., KiendlerScharr, A., Maenhaut, W., McFiggans, G., Mentel, T. F., Monod, A., Prévôt, A. S. H., Seinfeld, J. H., Surratt, J. D., Szmigielski, R., and Wildt, J.: The formation, properties and impact of secondary organic aerosol: current and emerging issues, Atmos. Chem. Phys., 9, 5155-5235, doi:10.5194/acp-9-5155-2009, 2009.

Hamburger, T., McMeeking, G., Minikin, A., Birmili, W., Dall'Osto, M., O’Dowd, C., Flentje, H., Henzing, B., Junninen, H., Kristensson, A., de Leeuw, G., Stohl, A., Burkhart, J. F., Coe, H., Krejci, R., and Petzold, A.: Overview of the synoptic and pollution situation over Europe during the EUCAARILONGREX field campaign, Atmos. Chem. Phys., 11, 10651082, doi:10.5194/acp-11-1065-2011, 2011.

Hasekamp, O. P., Litvinov, P., and Butz, A.: Aerosol properties over the ocean from PARASOL multiangle photopolarimetric measurements, J. Geophys. Res., 116, D14204, doi:10.1029/2010JD015469, 2011.

Hess, M., Koepke, P., and Schult, I.: Optical Properties of Aerosols and Clouds: The Software Package OPAC, B. Am. Meteorol. Soc., 79, 831-844, doi:10.1175/15200477(1998)079<0831:OPOAAC<2.0.CO;2, 1998.

Highwood, E. J., Northway, M. J., McMeeking, G. R., Morgan, W. T., Liu, D., Osborne, S., Bower, K., Coe, H., Ryder, C., and Williams, P.: Aerosol scattering and absorption during the EUCAARI-LONGREX flights of the Facility for Airborne Atmospheric Measurements (FAAM) BAe-146: can measurements and models agree?, Atmos. Chem. Phys., 12, 7251-7267, doi:10.5194/acp-12-7251-2012, 2012.

Hoffer, A., Gelencsér, A., Guyon, P., Kiss, G., Schmid, O., Frank, G. P., Artaxo, P., and Andreae, M. O.: Optical properties of humic-like substances (HULIS) in biomass-burning aerosols, Atmos. Chem. Phys., 6, 3563-3570, doi:10.5194/acp-6-3563-2006, 2006.

Holben, B. N., Eck, T. F., Slutsker, I., Tanre, D., Buis, J. P. Setzer, A., Vermote, E., Reagan, J. A., Kaufman, Y. F., Nakajima, T., Lavenu, F., Jankowiak, I., and Smirnov, A.: AERONET - A Federated Instrument Network and Data Archive for Aerosol Characterisation, Remote Sens. Environ., 66, 1-16, 1998. 
Holben, B. N., Eck, T. F., Slutsker, I., Smirnov, A., Sinyuk, A., Schafer, J. S., Giles, D. M., and Dubovik, O.: Aeronet's Version 2.0 quality assurance criteria, Proc. SPIE, 6408, 64080Q, doi:10.1117/12.70652, 2006.

Horvath, H.: Influence of atmospheric aerosols upon the global radiation balance, In Atmospheric Particles IUPAC Series on Analytical and Physical Chemistry of Environmental Systems, John Wiley, New York, 5, 543-596, 1998.

Jacobson, M. Z.,: Isolating nitrated and aromatic aerosols and nitrated aromatic gases as sources of ultraviolet light absorption, J. Geophys. Res., 104, 3527-3542, 1999.

Janzen, J.: The refractive index of colloidal carbon, J. Colloid Interface Sci., 69, 436-447, 1979.

Jeong, M. J., Li, Z., Andrews, E., and Tsay, S.-C.: Effect of aerosol humidification on the column aerosol optical thickness over the Atmospheric Radiation Measurement Southern Great Plains site, J. Geophys. Res., 112, D10202, doi:10.1029/2006JD007176, 2007.

Kahn, R. A.: Reducing the Uncertainties in Direct Aerosol Radiative Forcing, Surv. Geophys., 33, 701-721, doi:10.1007/s10712011-9153-z, 2012.

Kanakidou, M., Seinfeld, J. H., Pandis, S. N., Barnes, I., Dentener, F. J., Facchini, M. C., Van Dingenen, R., Ervens, B., Nenes, A., Nielsen, C. J., Swietlicki, E., Putaud, J. P., Balkanski, Y., Fuzzi, S., Horth, J., Moortgat, G. K., Winterhalter, R., Myhre, C. E. L., Tsigaridis, K., Vignati, E., Stephanou, E. G., and Wilson, J.: Organic aerosol and global climate odeling: a review, Atmos. Chem. Phys., 5, 1053-1123, doi:10.5194/acp-5-1053-2005, 2005.

Kandler, K., Lieke, K., Benker, N., Emmel, C., Küpper, M., MüllerEbert, D., Ebert, M., Scheuvens, D., Schladitz, A., Schütz, L., and Weinbruch, S.: Electron microscopy of particles collected at Praia, Cape Verde, during the Saharan Mineral Dust Experiment: particle chemistry, shape, mixing state and complex refractive index, Tellus B, 63, 475-496, 2011.

King, M. D., Kaufman, Y. J., Menzel, W., and Tanre, D.: Remote sensing of cloud, aerosol, and water vapor properties from the Moderate Resolution Imaging Spectrometer (MODIS), Geosci. Remote Sens., 30, 2-27, 1992.

Kinne, S., Lohmann, U., Feichter, J., Timmreck, C., Schulz, M., Ghan, S., Easter, R., Chin, M., Ginoux, P., Takemura, T., Tegen, I., Koch, D., Herzog, M., Penner, J., Pitari, G., Holben, B., Eck, T., Smirnov, A., Dubovik, O., Slutsker, I., Tanré, D., Torres, O., Mishchenko, M., Geogdzhayev, I., Chu, D. A., and Kaufman, Y.: Monthly Averages of Aerosol Properties: A Global comparison among models, satellite data and AERONET ground data, J. Geophys. Res., 108, 4634, doi:10.1029/2001JD001253, 2003.

Kirchstetter, T. W., Novakov, T., and Hobbs, P. V.: Evidence that the spectral dependence of light absorption by aerosols is affected by organic carbon, J. Geophys. Res., 109, D21208, doi:10.1029/2004JD004999, 2004.

Köhler, H.: The nucleus in the growth of hygroscopic droplets, Trans. Faraday Soc., 32, 1152-1161, 1936.

Köpke, P., Hess, M., Schult, I.,and Shettle, E. P.: Global Aerosol Data Set, Report No. 243, ISSN: 0937-1060, Max-PlanckInstitut für Meteorologie, Hamburg, 1997.

Koren, I., Remer, L., Kaufman, Y. J., Rudich, Y., and Martins, J.: On the twilight zone between clouds and aerosols, Geophys. Res. Lett., 34, L08805, doi:10.1029/2007GL029253, 2007.
Kulmala, M., Kerminen, V. M., Anttila, T., Laaksonen, A., and O'Dowd, C. D.: Organic aerosol formation via sulphate cluster activation, J. Geophys. Res, 109, D04205, doi:10.1029/2003JD003961, 2004.

Kulmala, M., Asmi, A., Lappalainen, H. K., Carslaw, K. S.,Pöschl, U., Baltensperger, U., Hov, Ø., Brenquier, J.-L., Pandis, S. N., Facchini, M. C., Hansson, H.-C., Wiedensohler, A., and O'Dowd, C. D.: Introduction: European Integrated project on Aerosol Cloud Climate and Air Quality interactions (EUCAARI) - integrating aerosol research from nano to global scales, Atmos. Chem. Phys., 9, 2825-2841, doi:10.5194/acp-9-2825-2009, 2009.

Kulmala, M., Asmi, A., Lappalainen, H. K., Baltensperger, U., Brenguier, J.-L., Facchini, M. C., Hansson, H.-C., Hov, Ø., O'Dowd, C. D., Pöschl, U., Wiedensohler, A., Boers, R., Boucher, O., de Leeuw, G., Denier van der Gon, H. A. C., Feichter, J., Krejci, R., Laj, P., Lihavainen, H., Lohmann, U., McFiggans, G., Mentel, T., Pilinis, C., Riipinen, I., Schulz, M., Stohl, A., Swietlicki, E., Vignati, E., Alves, C., Amann, M., Ammann, M., Arabas, S., Artaxo, P., Baars, H., Beddows, D. C. S., Bergström, R., Beukes, J. P., Bilde, M., Burkhart, J. F., Canonaco, F., Clegg, S. L., Coe, H., Crumeyrolle, S., D’Anna, B., Decesari, S., Gilardoni, S., Fischer, M., Fjaeraa, A. M., Fountoukis, C., George, C., Gomes, L., Halloran, P., Hamburger, T., Harrison, R. M., Herrmann, H., Hoffmann, T., Hoose, C., Hu, M., Hyvärinen, A., Hõrrak, U., Iinuma, Y., Iversen, T., Josipovic, M., Kanakidou, M., Kiendler-Scharr, A., Kirkevåg, A., Kiss, G., Klimont, Z., Kolmonen, P., Komppula, M., Kristjánsson, J.-E., Laakso, L., Laaksonen, A., Labonnote, L., Lanz, V. A., Lehtinen, K. E. J., Rizzo, L. V., Makkonen, R., Manninen, H. E., McMeeking, G., Merikanto, J., Minikin, A., Mirme, S., Morgan, W. T., Nemitz, E., O’Donnell, D., Panwar, T. S., Pawlowska, H., Petzold, A., Pienaar, J. J., Pio, C., Plass-Duelmer, C., Prévôt, A. S. H., Pryor, S., Reddington, C. L., Roberts, G., Rosenfeld, D., Schwarz, J., Seland, Ø., Sellegri, K., Shen, X. J., Shiraiwa, M., Siebert, H., Sierau, B., Simpson, D., Sun, J. Y., Topping, D., Tunved, P., Vaattovaara, P., Vakkari, V., Veefkind, J. P., Visschedijk, A., Vuollekoski, H., Vuolo, R., Wehner, B., Wildt, J., Woodward, S., Worsnop, D. R., van Zadelhoff, G.-J., Zardini, A. A., Zhang, K., van Zyl, P. G., Kerminen, V.-M., S Carslaw, K., and Pandis, S. N.: General overview: European Integrated project on Aerosol Cloud Climate and Air Quality interactions (EUCAARI) - integrating aerosol research from nano to global scales, Atmos. Chem. Phys., 11, 13061-13143, doi:10.5194/acp11-13061-2011, 2011.

Lesins, G., Chylek, P., and Lohmann, U.: A study of internal and external mixing scenarios and its effect on aerosol optical properties and direct radiative forcing, J. Geophys. Res., 107, 4094, doi:10.1029/2001JD000973, 2002.

Loeb, N. G. and Su, W.: Direct Aerosol Radiative Forcing Uncertainty Based on a Radiative Perturbation Analysis, J. Climate, 23, 5288-5293, doi:10.1175/2010JCLI3543.1, 2010.

Lohmann, U. and Feichter, J.: Global indirect aerosol effects: a review, Atmos. Chem. Phys., 5, 715-737, doi:10.5194/acp-5-7152005, 2005.

Lohmann, U., Rotstayn, L., Storelvmo, T., Jones, A., Menon, S., Quaas, J., Ekman, A. M. L., Koch, D., and Ruedy, R.: Total aerosol effect: radiative forcing or radiative flux perturbation?, 
Atmos. Chem. Phys., 10, 3235-3246, doi:10.5194/acp-10-32352010, 2010.

Marcolli, C. and Krieger, U. K... Phase changes during hygroscopic cycles of mixed organic/inorganic model systems of tropospheric aerosols, J. Phys. Chem. A., 110, 1881-1893, doi:10.1021/jp0556759, 2006.

McConnell, C. L., Formenti, P., Highwood, E. J., and Harrison, M. A. J.: Using aircraft measurements to determine the refractive index of Saharan dust during the DODO Experiments, Atmos. Chem. Phys., 10, 3081-3098, doi:10.5194/acp-10-30812010, 2010.

Mensah, A. A., Holzinger, R., Otjes, R., Trimborn, A., Mentel, T. F., ten Brink, H., Henzing, B., and Kiendler-Scharr, A.: Aerosol chemical composition at Cabauw, The Netherlands as observed in two intensive periods in May 2008 and March 2009, Atmos. Chem. Phys., 12, 4723-4742, doi:10.5194/acp-12-4723-2012, 2012.

Meyer, N. K., Duplissy, J., Gysel, M., Metzger, A., Dommen, J., Weingartner, E., Alfarra, M. R., Prévôt, A. S. H., Fletcher, C., Good, N., McFiggans, G., Jonsson, Å. M., Hallquist, M., Baltensperger, U., and Ristovski, Z. D.: Analysis of the hygroscopic and volatile properties of ammonium sulphate seeded and unseeded SOA particles, Atmos. Chem. Phys., 9, 721-732, doi:10.5194/acp-9-721-2009, 2009.

Mishchenko, M. I., Travis, L. D., Kahn, R. A., and West, R. A.: Modeling phase functions for dustlike tropospheric aerosols using a shape mixture of randomly oriented polydisperse spheroids. J. Geophys. Res., 102, 16831-16847, doi:10.1029/96JD02110, 1997.

Moelwyn-Hughes, E. A.: Physical Chemistry, 2nd rev. ed., p. 397, Pergamon, New York, 1961.

Morgan, W. T., Allan, J. D., Bower, K. N., Esselborn, M., Harris, B., Henzing, J. S., Highwood, E. J., Kiendler-Scharr, A., McMeeking, G. R., Mensah, A. A., Northway, M. J., Osborne, S., Williams, P. I., Krejci, R., and Coe, H.: Enhancement of the aerosol direct radiative effect by semi-volatile aerosol components: airborne measurements in North-Western Europe, Atmos. Chem. Phys., 10, 8151-8171, doi:10.5194/acp-10-81512010, 2010.

Myhre, G.: Consistency Between Satellite-Derived and Modeled Estimates of the Direct Aerosol Effect, Science 325, 187-190, doi:10.1126/science.1174461, 2009.

Myhre, G., Samset, B. H., Schulz, M., Balkanski, Y., Bauer, S., Berntsen, T. K., Bian, H., Bellouin, N., Chin, M., Diehl, T., Easter, R. C., Feichter, J., Ghan, S. J., Hauglustaine, D., Iversen, T., Kinne, S., Kirkevåg, A., Lamarque, J.-F., Lin, G., Liu, X., Lund, M. T., Luo, G., Ma, X., van Noije, T., Penner, J. E., Rasch, P. J., Ruiz, A., Seland, Ø., Skeie, R. B., Stier, P., Takemura, T., Tsigaridis, K., Wang, P., Wang, Z., Xu, L., Yu, H., Yu, F., Yoon, J.-H., Zhang, K., Zhang, H., and Zhou, C.: Radiative forcing of the direct aerosol effect from AeroCom Phase II simulations, Atmos. Chem. Phys., 13, 1853-1877, doi:10.5194/acp-13-18532013, 2013a.

Myhre, G., Myhre, C. E. L., Samset, B. H., and Storelvmo, T.: Aerosols and their Relation to Global Climate and Climate Sensitivity, Nature Educ. Knowl., 4, 7, 2013 b.

Nelder, J. A. and Mead, R.: A simplex method for function minimization, Comp. J., 7, 308-313, doi:10.1093/comjnl/7.4.308, 1965.
Oshima, N., Koike, M., Zhang, Y., and Kondo, Y.: Aging of black carbon in outflow from anthropogenic sources using a mixing state resolved model: 2. Aerosol optical properties and cloud condensation nuclei activities, J. Geophys. Res., 114, D18202, doi:10.1029/2008JD011681, 2009.

Péré, J. C., Mallet, M., Bessagnet, B., and Pont, V.: Evidence of the aerosol core-shell mixing state over Europe during the heat wave of summer 2003 by using CHIMERE simulations and AERONET inversions, Geophys. Res. Lett., 36, L09807, doi:10.1029/2009GL037334, 2009.

Petzold, A. and Schönlinner, M.: Multi-angle absorption photometry - a new method for the measurement of aerosol light absorption and atmospheric black carbon, J. Aerosol Sci., 35, 421-441, 2004.

Petzold, A., Schloesser, H., Sheridan, P. J., Arnott, W. P., Ogren, J. A., and Virkkula, A.: Evaluation of multiangle absorption photometry for measuring aerosol light absorption, Aerosol Sci. Technol., 39, 40-51, 2005.

Quaas, J., Boucher, O., Bellouin, N., and Kinne, S.: Satellite-based estimate of the direct and indirect aerosol climate forcing, J. Geophys. Res., 113, D05204, doi:10.1029/2007JD008962, 2008.

Quaas, J., Ming, Y., Menon, S., Takemura, T., Wang, M., Penner, J. E., Gettelman, A., Lohmann, U., Bellouin, N., Boucher, O., Sayer, A. M., Thomas, G. E., McComiskey, A., Feingold, G., Hoose, C., Kristjánsson, J. E., Liu, X., Balkanski, Y., Donner, L. J., Ginoux, P. A., Stier, P., Feichter, J., Sednev, I., Bauer, S. E., Koch, D., Grainger, R. G., Kirkevåg, A., Iversen, T., Seland, Ø., Easter, R., Ghan, S. J., Rasch, P. J., Morrison, H., Lamarque, J.F., Iacono, M. J., Kinne, S., and Schulz, M.: Aerosol indirect effects - general circulation model intercomparison and evaluation with satellite data, Atmos. Chem. Phys., 9, 8697-8717, doi:10.5194/acp-9-8697-2009, 2009.

Richardson, C. B. and Hightower, R. L.: Evaporation of ammonium nitrate particles, Atmos. Environ., 21, 971-975, 1987.

Roelofs, G. J. and Kamphuis, V.: Cloud processing, cloud evaporation and Angström exponent, Atmos. Chem. Phys., 9, 71-80, doi:10.5194/acp-9-71-2009, 2009.

Roelofs, G. J., ten Brink, H., Kiendler-Scharr, A., de Leeuw, G., Mensah, A., Minikin, A., and Otjes, R.: Evaluation of simulated aerosol properties with the aerosol-climate model ECHAM5HAM using observations from the IMPACT field campaign, Atmos. Chem. Phys., 10, 7709-7722, doi:10.5194/acp-10-77092010, 2010.

Russchenberg, H. W. J., Bosveld, F., Swart, D. P. J., ten Brink, H., de Leeuw, G., Uijlenhoet, R., Arbesser-Rastburg, B., van der Marel, H., Ligthart, L., Boers, R., and Apituley, A.: Groundbased atmospheric remote sensing in The Netherlands; European outlook, IEICE Trans. Comm., E88-B(6), 2252-2258, doi:10.1093/ietcom/e88-b.6.2252, 2005.

Russell, P. B., Bergstrom, R. W., Shinozuka, Y., Clarke, A. D., DeCarlo, P. F., Jimenez, J. L., Livingston, J. M., Redemann, J., Dubovik, O., and Strawa, A.: Absorption Angstrom Exponent in AERONET and related data as an indicator of aerosol composition, Atmos. Chem. Phys., 10, 1155-1169, doi:10.5194/acp-101155-2010, 2010.

Schaap, M., Apituley, A., Timmermans, R. M. A., Koelemeijer, R. B. A., and De Leeuw, G.: Exploring the relation between aerosol optical depth and $\mathrm{PM}_{2.5}$ at Cabauw, the Netherlands, Atmos. Chem. Phys., 9, 909-925, doi:10.5194/acp-9-909-2009, 2009. 
Schaap, M., Otjes, R. P., and Weijers, E. P.: Illustrating the benefit of using hourly monitoring data on secondary inorganic aerosol and its precursors for model evaluation, Atmos. Chem. Phys., 11, 11041-11053, doi:10.5194/acp-11-11041-2011, 2011.

Schulz, M., Chin, M., and Kinne, S.: The Aerosol Model Comparison Project, AeroCom, phase II: Clearing up diversity, IGAC Newsletter No. 41, 2-11, 2009.

Schuster, G. L., Dubovik, O., Holben, B. N., and Clothiaux, E. E.: Inferring black carbon content and specific absorption from Aerosol Robotic Network (AERONET) aerosol retrievals, J. Geophys. Res., 110, D10S17, doi:10.1029/2004JD004548, 2005.

Schuster, G. L., Lin, B., and Dubovik, O.: Remote sensing of aerosol water uptake, Geophys. Res. Lett., 36, L03814, doi:10.1029/2008GL036576, 2009.

Segelstein, D. J.: The complex refractive index of water, Master's thesis, Department of Physics, University of Missouri-Kansas City, 1981.

Seinfeld, J. H. and Pandis, S. N.: Atmospheric Chemistry and Physics, John Wiley, New York, 455-461, 1998.

Shettle, E. P. and Fenn, R. W.: Models for the aerosols for the lower atmosphere and the effects of humidity variations on their optical properties, AFGL-TR-79-0214, Environ. Res. Pap. 676, 1979.

Sjogren, S., Gysel, M.,Weingartner, E., Baltensperger, U., Cubison, M. J., Coe, H., Zardini, A. A., Marcolli, C., Krieger, U. R., and Peter, T.: Hygroscopic growth and water uptake kinetics of twophase aerosol particles consisting of ammonium sulphate, adipic and humic acid mixtures, J. Aerosol Sci., 38, 157-171, 2007.

Smirnov, A., Holben, B. N., Eck, T. F., Dubovik, O., and Slutsker, I.: Cloud screening and quality control algorithms for the AERONET data base, Remote Sens. Environ., 73, 337-349, 2000.

Sokolik, I. N., Andronova, A. V., and Johnson T. C.: Complex refractive index of atmospheric dust aerosols, Atmos. Environ., 27, 2495-2502, 1993.

Song, M., Marcolli, C., Krieger, U. K., Zuend, A., and Peter, T.: Liquid-liquid phase separation and morphology of internally mixed dicarboxylic acids/ammonium sulfate/water particles, Atmos. Chem. Phys., 12, 2691-2712, doi:10.5194/acp-12-26912012, 2012.

Stelson, A. W.: Urban aerosol refractive index prediction by partial molar refraction approach, Environ. Sci. Technol. 24, 16761679, 1990.

Stier, P., Seinfeld, J.H., Kinne, S., and Boucher, O.: Aerosol absorption and radiative forcing, Atmos. Chem. Phys. 7, 5237-5261, doi:10.5194/acp-7-5237-2007, 2007.

Stokes, R. H. and Robinson, R. A.: Interactions in aqueous nonelectrolyte solutions: I. Solute-solvent equilibria, J. Phys. Chem., 70, 2126-2130, 1966.

Sun, H., Biedermann, L., and Bond, T. C.: Color of brown carbon: A model for ultraviolet and visible light absorption by organic carbon aerosol, Geophys. Res. Lett., 34, L17813, doi:10.1029/2007GL029797, 2007.

Svenningsson, B., Rissler, J., Swietlicki, E., Mircea, M., Bilde, M., Facchini, M. C., Decesari, S., Fuzzi, S., Zhou, J., Mønster, J., and Rosenørn, T.: Hygroscopic growth and critical supersaturations for mixed aerosol particles of inorganic and organic compounds of atmospheric relevance, Atmos. Chem. Phys., 6, 1937-1952, doi:10.5194/acp-6-1937-2006, 2006.
Tang, I. N.: Chemical and size effects of hygroscopic aerosols on light scattering coefficients, J. Geophys. Res., 101, 1924519250, doi:10.1029/96JD03003, 1996.

Tang, I. N.: Thermodynamic and optical properties of mixed-salt aerosols of atmospheric importance, J. Geophys. Res., 102, 1883-1893, 1997.

Tang, I. N. and Munkelwitz, H. R.: Composition and temperature dependence of the deliquescence properties of hygroscopic aerosol, Atmos. Environ., 27A, 467-473, doi:10.1016/09601686(93)90204-C, 1993.

Tang, I. N. and Munkelwitz, H. R.: Water activities, densities, and refractive indices of aqueous sulfates and sodium nitrate droplets of atmospheric importance, J. Geophys. Res., 20, 18801-18808, 1994.

Tang, I. N., Tridico, A. C., and Fung, K. H. Fung: Thermodynamic and optical properties of sea-salt aerosols, J. Geophys. Res., 102, 23269-23276, 1997.

Tanré, D., Bréon, F. M., Deuzé, J. L., Dubovik, O., Ducos, F., François, P., Goloub, P., Herman, M., Lifermann, A., and Waquet, F.: Remote sensing of aerosols by using polarized, directional and spectral measurements within the A-Train: the PARASOL mission, Atmos. Meas. Tech, 4, 1383=-1395, doi:10.5194/amt-4-1383-2011, 2011.

ten Brink, H., Otjes, R., Jongejan, P., and Slanina, S.: An instrument for semi-continuous monitoring of the size-distribution of nitrate, ammonium, sulphate and chloride in aerosol, Atmos. Environ., 41, 2768-2779, doi:10.1016/j.atmosenv.2006.11.041, 2007.

Thomas, R. M., Trebs, I., Otjes, R., Jongejan, P. A. C., ten Brink, H., Phillips, G., Kortner, M., Meixner, F. X., and Nemitz, E.: An automated analyzer to measure surface-atmosphere exchange fluxes of water soluble inorganic aerosol compounds and reactive trace gases, Environ. Sci. Technol., 43, 1412-1418, doi:10.1021/es8019403, 2009.

Toon, O. B., Pollack, J. B., and Khare, B. N.: Optical constants of several atmospheric aerosol species: ammonium sulfate, aluminum oxide, and sodium chloride, J. Geophys. Res., 81, 57335748, doi:10.1029/JC081i033p05733, 1976.

Torres, B.: Study on the influence of different error sources on sky radiance measurements and inversion-derived aerosol products in the frame of AERONET, PhD Thesis, http://goa.uva.es/papers/ Tesis_BTorres.pdf, 2012.

Torres, B., Dubovik, O., Toledano, C., Berjon, A., Cachorro, V. E., Lapyonok, T., Litvinov, P., and Goloub, P.: Sensitivity of aerosol retrieval to geometrical configuration of ground-based sun/sky radiometer observations, Atmos. Chem. Phys., 14, 847-875, doi:10.5194/acp-14-847-2014, 2014.

Turpin, B. J. and Lim, H. J.: Species contributions to $\mathrm{PM}_{2.5}$ mass concentrations: Revisiting common assumptions for estimating organic mass, Aerosol Sci. Technol. 35, 602-610, 2001.

van Beelen, A. J. and van Delden, A. J.: Cleaner air brings better views, more sunshine and warmer summer days in the Netherlands, Weather, 67, 21-25, doi:10.1002/wea.854, 2012.

Wagner, F., Bortoli, D., Pereira, S., Costa, M., Silva, A. M., Weinzierl, B., Esselborn, M., Petzold, A., Rasp, K., Heinold, B., and Tegen, I.: Properties of dust aerosol particles transported to Portugal from the Sahara desert, Tellus B, 61, 297-306, 2009.

Wagner, R., Ajtai, T., Kandler, K., Lieke, K., Linke, C., Müller, T., Schnaiter, M., and Vragel, M.: Complex refractive indices of Saharan dust samples at visible and near UV wave- 
lengths: a laboratory study, Atmos. Chem. Phys., 12, 2491-2512, doi:10.5194/acp-12-2491-2012, 2012.

Wang, J., Hoffmann, A. A., Park, R. J., Jacob, D. J., and Martin, S. T.: Global distribution of solid and aqueous sulfate aerosols: Effect of the hysteresis of particle phase transition, J. Geophys. Res., 103, D11206, doi:10.1029/2007JD009367, 2008.

Wang, K., Dickinson, R. E., and Liang, S.: Clear sky visibility has decreased over land globally from 1973 to 2007, Science, 323, 1468-1470, 2009.

Wang, L., Li, Z., Tian, Q., Ma, Y., Zhang, F., Zhang, Y., Li, D., Li, K., and Li, L.: Estimate of aerosol absorbing components of black carbon, brown carbon, and dust from ground-based remote sensing data of sun-sky radiometers, J. Geophys. Res. Atmos., 118, 6534-6543, doi:10.1002/jgrd.50356, 2013.

Weast, R. C.: Handbook of Chemistry and Physics, 66th edn., CRC Press, Florida, USA, p. E-365, 1985.

Weast, R.C.: Physical constants of organic compounds, CRC Handbook of Chemistry and Physics, 68th Edition, edited by: Weast, R. C., CRC Press, Boca Raton, FL, B67-B146, 1987.

Yu, H., Quinn, P. K., Feingold, G., Remer, L. A., Kahn, R. A., Chin, M., and Schwartz, S. E.: Remote Sensing and In Situ Measurements of Aerosol Properties, Burdens, and Radiative Forcing, in Atmospheric Aerosol Properties and Climate Impacts, A Report by the U.S. Climate Change Science Program and the Subcommittee on Global Change Research, edited by: Chin, M., Kahn, R. A., and Schwartz, S. E., National Aeronautics and Space Administration, Washington, D.C., USA, 2009.
Zdanovskii, A. B.: Trudy Solyanoi Laboratorii Akad. Nauk SSSR, No. 2, 1936.

Zhang, K., O’Donnell, D., Kazil, J., Stier, P., Kinne, S., Lohmann, U., Ferrachat, S., Croft, B., Quaas, J., Wan, H., Rast, S., and Feichter, J.: The global aerosol-climate model ECHAM-HAM, version 2: sensitivity to improvements in process representations, Atmos. Chem. Phys., 12, 8911-8949, doi:10.5194/acp-12-89112012, 2012.

Zieger, P., Weingartner, E., Henzing, J., Moerman, M., de Leeuw, G., Mikkilä, J., Ehn, M., Petäjä, T., Clémer, K., van Roozendael, M., Yilmaz, S., Frieß, U., Irie, H., Wagner, T., Shaiganfar, R., Beirle, S., Apituley, A., Wilson, K., and Baltensperger, U.: Comparison of ambient aerosol extinction coefficients obtained from in-situ, MAX-DOAS and LIDAR measurements at Cabauw. Atmos. Chem. Phys., 11, 2603-2624, doi:10.5194/acp11-2603-2011, 2011.

Zieger, P., Fierz-Schmidhauser, R., Weingartner, E., and Baltensperger, U.: Effects of relative humidity on aerosol light scattering: results from different European sites, Atmos. Chem. Phys., 13, 10609-10631, doi:10.5194/acp-13-10609-2013, 2013. 